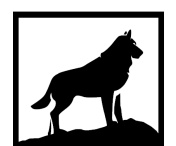

Michigan Technological

1 8 8 5 University
Michigan Technological University Digital Commons @ Michigan Tech

2018

THE EFFECT OF WATER TABLE LEVELS AND SHORT-TERM DITCH RESTORATION ON MOUNTAIN PEATLAND CARBON CYCLING IN THE CORDILLERA BLANCA, PERU

Ana Maria Planas Clarke

Michigan Technological University, aplanasc@mtu.edu

Copyright 2018 Ana Maria Planas Clarke

Recommended Citation

Planas Clarke, Ana Maria, "THE EFFECT OF WATER TABLE LEVELS AND SHORT-TERM DITCH

RESTORATION ON MOUNTAIN PEATLAND CARBON CYCLING IN THE CORDILLERA BLANCA, PERU", Open Access Master's Thesis, Michigan Technological University, 2018.

https://doi.org/10.37099/mtu.dc.etdr/614

Follow this and additional works at: https://digitalcommons.mtu.edu/etdr 


\title{
THE EFFECT OF WATER TABLE LEVELS AND SHORT-TERM DITCH RESTORATION ON MOUNTAIN PEATLAND CARBON CYCLING IN THE CORDILLERA BLANCA, PERU
}

\author{
By \\ Ana Maria Planas Clarke
}

\author{
A THESIS \\ Submitted in partial fulfillment of the requirements for the degree of \\ MASTER OF SCIENCE \\ In Applied Ecology \\ MICHIGAN TECHNOLOGICAL UNIVERSITY \\ 2018 \\ (C) 2018 Ana Maria Planas Clarke
}


This thesis has been approved in partial fulfillment of the requirements for the Degree of MASTER OF SCIENCE in Applied Ecology.

School of Forest Resources and Environmental Science

\author{
Thesis Co-Advisor: Rodney Chimner \\ Thesis Co-Advisor: Erik Lilleskov \\ Committee Member: Molly Cavaleri
}

School Dean: Terry Sharik 


\section{Table of Contents}

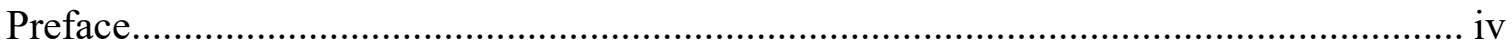

Acknowledgements .....................................................................................................

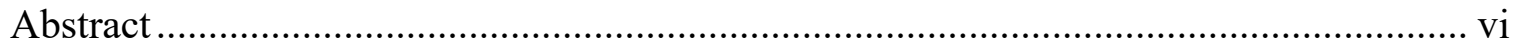

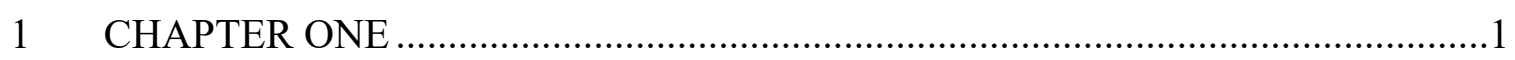

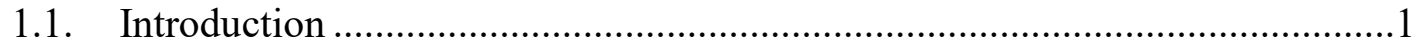

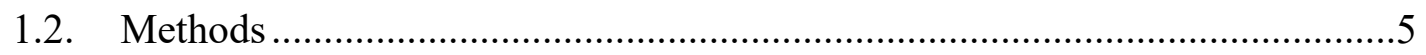

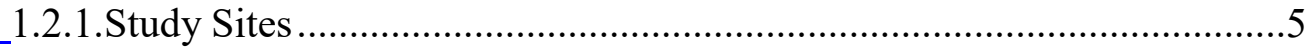

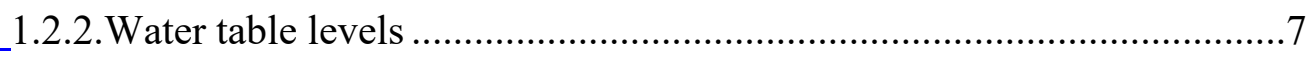

1.2.3. $\mathrm{CO}_{2}$ flux measurements.............................................................

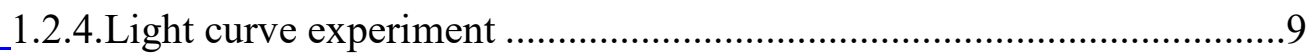

1.2.5. $\mathrm{CH}_{4}$ flux measurements....................................................................

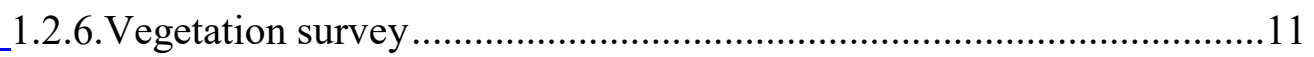

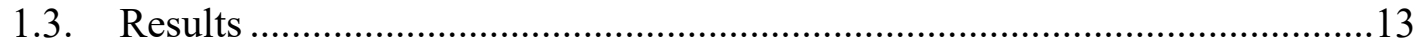

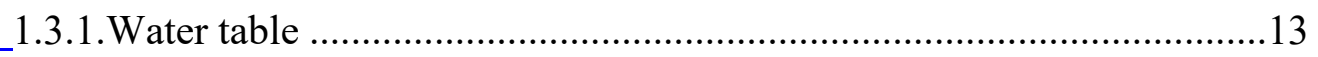

1.3.2. Vegetation survey and plant productivity ...............................................13

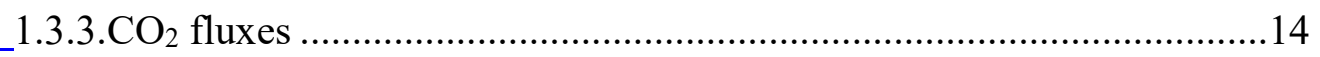

1.3.4.Light response curves .........................................................................16

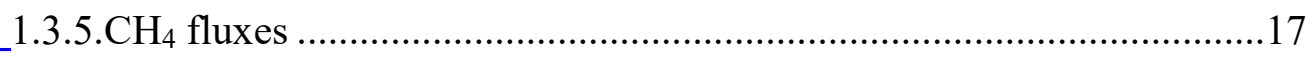

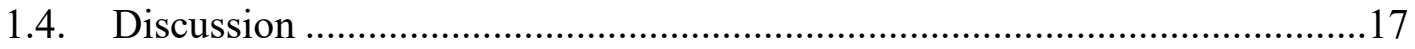

1.4.1.Hydrologically undisturbed sites.........................................................17

1.4.2. Response to water table drawdown .......................................................19

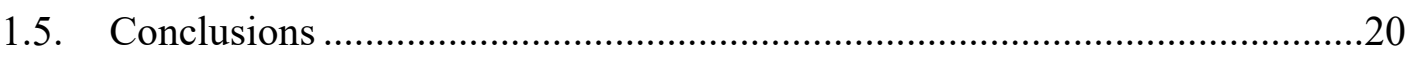

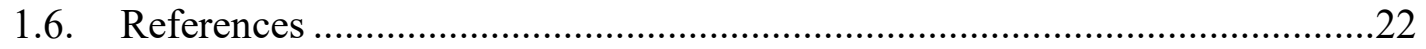

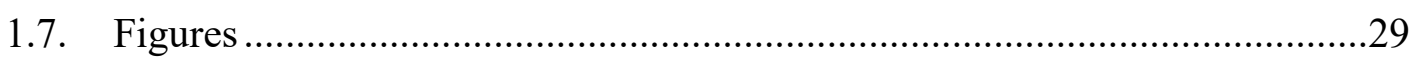

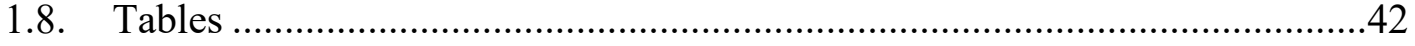




\section{Preface}

The journal article which is included as the main body of this manuscript is planned for submission in the near future and was written by Ana Maria Planas Clarke.

Data collection and processing were done by Planas, as well as figures and tables.

Rod Chimner provided the experimental design and editing advice and assistance.

John Hribljan provided gas flux measurement training, constructed the gas chambers and offered valuable advice on technical issues on the field.

Erik Lilleskov provided significant insights to the project design as well as essential editing assistance.

Beatriz Fuentealba and The Mountain Institute (TMI) helped collecting $\mathrm{CO}_{2}$ data in the field 


\section{Acknowledgements}

I would like to start by thanking my family, my dad and sisters, for their love and support through this whole process.

Infinite thanks to Rod Chimner, Erik Lilleskov, and John Hribljan, who shared their knowledge, wisdom, and so many wonderful moments with me. Thank you Molly Cavaleri for being part of the committee and for your inputs to this project.

Special thanks to the SWAMP program for the financial support to carry out this project, and to The Mountain Institute in Peru and the field crew: Beatriz Fuentealba, Mayra Mejía, Edwin Giraldo, Yanett Gonzáles, and Yomel Huamán who collected fundamental data for the project while I was taking classes at MTU.

Thank you to all the friends who virtually accompanied me throughout this journey: Craig Wayson, Sofía Piqué, Svetka Kuljich, Verónica Gálmez, Susana Yturry, Ricardo Agama, Gracile Sangay, and so many others who made me feel their presence despite the distance.

Thank you to the new friends who were the nicest, kindest people I would have crossed paths with: Ezequiel Médici, Jhon Del Aguila (Pashkito), Kelsey Carter, Danielle Rupp, Ulises Grácida, Mayra Sánchez, Rachel and Adam Rulison, and all the people at the U.S. Forest Service. You made my staying here wonderful and unforgettable. We will see each other again. 


\section{Abstract}

Tropical mountain peatlands are abundant in the Andes but are under intense grazing pressure and subject to climate change, both of which alter hydrologic conditions. Therefore, our first objective was to assess how carbon dioxide $\left(\mathrm{CO}_{2}\right)$ and methane $\left(\mathrm{CH}_{4}\right)$ fluxes change across a hydrological gradient in a mountain peatland in Huascaran National Park, Peru. Our second objective was to evaluate how short-term carbon cycling is changed after rewetting from ditch blocking. $\mathrm{CO}_{2}$ and $\mathrm{CH}_{4}$ effluxes were measured using the static chamber method. Net ecosystem exchange in the reference and the unrestored areas were on average $1.07 \pm 0.06$, and $0.76 \pm 0.11 \mathrm{~g} \mathrm{CO}_{2} \mathrm{~m}^{-2} \mathrm{hr}^{-1}$. Although this is a groundwater fed peatland, we found that drained areas responded more to seasonal precipitation. Unexpectedly, ecosystem respiration in the unrestored treatment increased as water table rose in the rainy season. $\mathrm{CH}_{4}$ emissions were $2.76 \pm 1.06 \mathrm{mg}$ $\mathrm{CH}_{4} \mathrm{~m}^{-2}$ day $^{-1}$ on average. However, at water table levels below $-10 \mathrm{~cm}, \mathrm{CH}_{4}$ fluxes were zero. Although establishing the effect of restoration was complicated in this study by the timing of the wet season, our results indicate that rewetting increased Net Ecosystem Exchange and the ability to store carbon to near reference conditions. 


\section{CHAPTER ONE}

\subsection{Introduction}

Peatlands are wetlands that have accumulated thick layers of organic matter. The majority of peatlands globally are found in low-elevation areas, primarily in boreal and tropical regions (Clymo 1987: Maltby \& Proctor, 1996). However, peatlands are also common in many mountain ranges, including the Andes (Cooper et al. 2012). Peatlands are common throughout the Andes, occurring in several climate zones including (1) the northern páramo ecoregion (wet year round) of Colombia, Venezuela, and Ecuador, usually above 3,500 m (Samaniego et al. 1998; Chimner and Karberg 2008; Hribljan et al. 2016), (2) high elevation (3000 - 4,800 m) mesic jalca ecoregion of northern Peru, where they are locally known as "bofedales" (Cooper et al. 2010), and (3) the very high (4400-4800 m) and arid puna ecoregion that extends from southern Peru through Bolivia (Cooper et al. 2015; Hribljan et al. 2015) to northern Chile and Argentina (Earle et al. 2003; Preston et al. 2003).

In contrast to Sphagnum-dominated northern peatlands, many Andean mountain peatlands are dominated by vascular plants with a cushion life form (Cooper et al. 2010). Many common cushion plant species are in the family Juncaceae, and other species are in the families Plantaginaceae and Asteraceae (Cooper et al. 2010; Benavides 2014;

Salvador et al. 2014). Cushion plants have a dense, low-statured growth form with long taproots or buried stems with adventitious roots (Cooper et al. 2015). The cushion plant growth form has undergone convergent evolution in several regions as an adaption to 
arctic and alpine environments (Billings and Mooney 1968). The compact growth form can trap heat and warm plants up to $\sim 15^{\circ} \mathrm{C}$ above the surrounding air temperature and increase vegetation canopy humidity by reducing wind shear and evapotranspiration. In addition, their deep roots can acquire deep soil moisture and increase access to nutrients buried in decomposing tissues as the cushions grow upward. The aerenchymatous tissue of the roots can also transport gases from the surface to deep layers of peat and vice versa. The physiological and morphological characteristics of cushion plants are vastly different from common sedges and Sphagnum moss species that dominate most boreal and temperate peatlands (Earle et al. 2003; Fritz et al. 2011; Salvador et al. 2014).

Biological processes in peatlands generally have been found to be strongly controlled by water table levels (Chimner and Cooper 2003b; Page et al. 2009; Silvola et al. 2010; Gatis et al. 2016; Chimner et al. 2017). The water table is a physical barrier to oxygen diffusion from the atmosphere into the peat, limiting microbial activity and slowing decomposition rates ( Maltby and Proctor 1996, Oechel, W. et al. 1998). A declining water table increases the volume of oxic soil and increases $\mathrm{CO}_{2}$ production, while decreasing anaerobically produced $\mathrm{CH}_{4}$ (Mooret and Knowles 1989; Bubier et al. 1995; Liblik et al. 1997; Nykänen et al. 1998; Silvola et al. 2010)

However, the relationship between water table level and carbon cycling is modified by vegetation type. For instance, Sphagnum mosses do not have roots and are sensitive to changes in water tables (Turetsky 2002; Bubier et al. 2003; Vasander and Kettunen 2006). A first study done in a cushion dominated peatland in the Ecuadorian páramo revealed that disturbances by cattle are detrimental to greenhouse gas benefits 
from mountain peatlands (Sanchez et al. 2017), however no studies have been done focusing on changes in hydrology. Since cushion plants have such different morphology and rooting strategies than plants in northern peatlands, it is unclear how cushion plant peatlands respond to changing water table levels.

$\mathrm{CH}_{4}$ emissions in peatlands are also strongly modified by vegetation type, with graminoids (e.g., sedges and rushes) having been found to enhance rates of $\mathrm{CH}_{4}$ emissions because labile root exudates increase $\mathrm{CH}_{4}$ production (Vasander and Kettunen 2006) and vascular aerenchymatous tissue (air channels in roots) increases $\mathrm{CH}_{4}$ transport when $\mathrm{O}_{2}$ flux through roots is insufficient to support high methanotroph $\left(\mathrm{CH}_{4}\right.$-oxidizing bacteria) activity (Schütz et al. 1990; Shannon and White 1994; Chanton 2005). However, in the few studies that have been carried out in intact cushion peatlands, cushion plant peatlands have been found to have very low $\mathrm{CH}_{4}$ flux rates, which has been attributed to high oxidation by cushion plant roots (Fritz et al. 2011; Dullo et al. 2017; Sanchez et al. 2017).

Mountain peatlands in the Andes have undergone hydrologic changes from both climate change and pastoral activities. Climate change can be one causal agent of hydrologic change, as exemplified by rapid Andean deglaciation in recent decades (Bradley et al. 2006). Even though the consequences of climate change are somewhat uncertain, it is expected that precipitation patterns will change in the Andean region, and that temperatures will increase, drying the peatlands (Chimner and Cooper 2003b; Cooper et al. 2015). In addition to climate change, many Andean mountain peatlands are being manipulated for grazing. Local communities have been farming sheep and cattle 
for over 200 years, and to facilitate grazing they often build ditches to drain the peatlands. This has changed the distribution of the natural vegetation communities as well as their ecological functions (Millones 1982).

Peatland hydrologic restoration could be a good strategy to reverse degradation due to ditching in the Andes (Chimner et al. 2017). It could potentially return the water table to natural levels and regain the $\mathrm{C}$ sink function of the ecosystem (Page et al. 2009; Luan et al. 2018). There are two main techniques to restore hydrology in drained peatlands, ditch-filling or ditch-blocking Chimner et al. (2017). Filling ditches is a good long-term technique, but can be difficult due to lack of suitable fill material and cost of filling. Blocking ditches is a more common method because it is often easier and less expensive than filling ditches (Chimner et al. 2017). However, it is unclear if this method will be effective in the sloping peatlands with incised channels sometimes found in the central Peruvian Andes.

Because there is little fundamental information on carbon cycling in hydrologically intact cushion peatlands, and even less is known about how cushion plant peatlands in the Andes respond to drainage or restoration, our goals of this study are to examine two questions: 1) how does carbon cycling vary along a water table gradient caused by ditching, and 2) how does carbon cycling change in the short-term (months to a year) after ditch restoration in a cushion plant peatland. We hypothesized that changes in water table will affect $\mathrm{CO}_{2}$ fluxes, by increasing ecosystem respiration (ER) at lower water table levels, and increasing net ecosystem exchange (NEE) at higher water table levels. We also hypothesized that $\mathrm{CH} 4$ emissions will increase with high water table 
levels in the cushion plant dominated areas. In terms of the restoration, we hypothesized that rewetting the area will bring the $\mathrm{CO}_{2}$ fluxes rates closer to those in the reference areas.

\subsection{Methods}

\subsubsection{Study Sites}

The study occurred in Huascaran National Park (HNP), in the Ancash region in the central Andes of Peru (Figure 1). The park has an area of 340,000 ha and covers an elevation range of 2,500 to 6,768 masl. HNP contains approximately 660 glaciers and 300 lagoons of glacial origin. Its glaciers feed the main hydrological basins in northcentral Peru. The mean annual precipitation of nearby Huaraz (elevation 3050 masl) is $632 \mathrm{~mm}$ and the mean annual temperature is $13.5^{\circ} \mathrm{C}$. The wet season occurs typically between October and April and has a mean temperature of $13.8^{\circ} \mathrm{C}$ and mean precipitation of $83 \mathrm{~mm}$ per month. The dry season occurs between May and September and has a mean temperature and precipitation of $13.1^{\circ} \mathrm{C}$ and $10.4 \mathrm{~mm}$ per month respectively (climate-data.org).

Many areas inside the park are currently under pressure, mainly because of climate change and overgrazing (Byers 2000). One consequence of climate change is that melting glaciers are increasing lakes in size and volume, becoming a potential risk for flooding the main city of Huaraz (Vilímek et al. 2005). Overgrazing reduces the natural plant cover, erodes the soil, and destabilizes the water and carbon cycle. For 
these reasons, park authorities are implementing management strategies to avoid disasters and recuperate ecosystems like bofedales using restoration.

The research occurred in two groundwater fed peatlands in the Tambillos region. Site 1 occurred in a small valley-bottom cushion fen peatland of approximately 4 ha located near the top of the watershed ( 4400 masl: S 9 $41^{\prime} 14.51$ ”, W $77^{\circ} 14^{\prime} 54.25^{\prime \prime}$ Figure 1) and is used as a reference location as it has no ditching disturbances. Due to the location of the peatland, it appears that it also has had little or no grazing impacts. Peat depth in this peatland is $\sim 415 \mathrm{~cm}$ and has a basal date of $8,365 \mathrm{yr}$. BP (Hribljan et al. unpublished data). Specific conductivity averaged $180 u \mathrm{~S} \mathrm{~cm}^{-1}$ and the $\mathrm{pH}$ was 5.8 .

Site 2 is a peatland complex of approximately 7 ha located $\sim 500 \mathrm{~m}$ down-valley from site 1 at $\sim 4200$ masl (S $9^{\circ} 41^{\prime} 21.80^{\prime \prime}, \mathrm{W} 77^{\circ} 14^{\prime} 18.40 "$, Figure 1). The peatland complex slopes down into and along the valley bottom and is bordered by a road on the one side (Fig 1). Peat depth in this peatland is $\sim 400 \mathrm{~cm}$ and has a basal date of $9,340 \mathrm{yr}$. BP (Hribljan et al. unpublished data). Specific conductivity averaged $112 u \mathrm{~S} \mathrm{~cm}^{-1}$ and the $\mathrm{pH}$ averaged 5.9. Local communities built ditches near the road to drain part of the peatland. Although the ditch construction date is unknown, local residents confirm that they have been there for over 10 years. Ditch sizes ranged between $30-50 \mathrm{~m}$ length, and $50-100 \mathrm{~cm}$ depth. Other parts of the peatland complex had low levels of grazing and receive groundwater inputs from the slopes on the side of the valley opposite of the road and ditches, so were hydrologically unaltered. We used two locations in these relatively undisturbed areas as additional reference locations (reference). Three additional locations were sampled along the length of the ditch before and after restoration 
(rewetted). One sampling location was located in a ditched area near the road that was not restored (unrestored).

Measurements began in June 2015 and occurred monthly until August 2016, then occurred one more time in December 2016. Sampling occurred for 5 months before any restoration occurred, during the dry season of 2015. In October 2015, at the beginning of the wet season, the peatland was restored by the Mountain Institute, Michigan Technological University, and local community members. Ditch restoration involved blocking the ditch with 22 wooden check dams (Figure 3). The size of the check dams ranged from 1-4 m wide, and $0.4-1.5 \mathrm{~m}$ high. Measurements continued after restoration until August 2016 and again in December 2016.

\subsubsection{Water table levels}

At each of the seven locations we installed a polyvinyl chloride (PVC) well to measure the water table. The wells were $6.3 \mathrm{~cm}$ in diameter and 1 to $2 \mathrm{~m}$ long. All wells were perforated, covered with a fine mesh, and capped to exclude infiltration from rain. Three wells were placed in the reference areas, three in the rewetted area, and the last one was installed in the unrestored area (Fig. 2). Water table depths were measured manually once a month for 17 months, from June 2015 until August 2016, and then again in December 2016 and May 2017. 


\subsection{3. $\mathrm{CO}_{2}$ flux measurements}

Daytime net cosystem exchange (NEE), ecosystem respiration (ER), and (by difference) gross primary productivity (GPP) were measured once a month starting in June 2015 until August 2016 and again in December 2016 using a chamber-based method (Hutchinson and Mosier 1981) and a PP Systems EGM-4 infrared gas analyzer (IRGA; PP Systems, Amesbury, USA)). The cylindrical chamber was custom made using clear acrylic (diameter $40.6 \mathrm{~cm}$, height $59 \mathrm{~cm}$, volume 76,383 $\mathrm{cm}^{3}$ ) (Sanchez et al. 2017). It was equipped with a detachable lid, a fan and a vent valve. Before conducting the experiment, four PVC collars (diameter $40.6 \mathrm{~cm}$, height $10 \mathrm{~cm}$, and wall thickness 0.5 $\mathrm{cm}$ ) with a sharpened lower edge were inserted $\sim 5 \mathrm{~cm}$ into the peat at $\sim 1$ to $3 \mathrm{~m}$ distance from each groundwater monitoring well as a fixed base for the chamber measurements.

To measure NEE, the clear chamber was placed carefully on the collar, without damaging the vegetation inside, and the collar-chamber joint was sealed using a cylindrical cut section of rubber tire inner tubing. With the fan on and the lid off, the chamber was flushed before each measurement, and then closed and sealed to conduct the measurements. NEE had a negative sign when GPP was higher than ER, meaning ecosystem uptake. The measurements were taken over a 124 seconds period. The same method was used to capture ER, except we placed a lightproof white cloth cover over the chamber to prevent light from entering the chamber. All measurements took place between 10:00 and 16:00, and collars were measured in random order to avoid any systematic bias. 
We measured several environmental parameters during flux measurements including water table level, time of the measurement, air temperature, soil temperature, relative humidity, barometric pressure using a barometer, and photosynthetically active radiation (PAR) using a PAR sensor. Some of these measurements, such as time of measurement, relative humidity, and barometric pressure were already recorded by the IRGA, however, we measured them as a back up to confirm that the equipment was working properly. PP Systems soil temperature probe (STP) was inserted into the soil next to the chamber at $5 \mathrm{~cm}$ during the light measurements and at $20 \mathrm{~cm}$ depth during the dark measurements, while an additional small temperature probe was also inserted into the soil, at the same depths as PP Systems STP, to compare values.

\subsubsection{Light curve experiment}

We developed a light response experiment to understand if the light compensation point (LCP) differs along the water table gradient. To develop light response curves, we used shade cloths of different mesh sizes to reduce light. This experiment followed the methods of (Whiting et al. 1992; Bubier et al. 1998), using a clear chamber, an IRGA, and shade cloths that provided $100 \%, 90 \%, 80 \%, 70 \%, 60 \%, 50 \%, 40 \%$ and $30 \%$ shade.

The measurements took place in May and June 2016, from 9:00 to 13:00 when wells were in direct sunlight and the sky was clear. We used the chamber-based methods described above. Six collars were measured: three in the rewetted area, two in the reference area, and one in the unrestored area. As with the regular NEE and ER measurements, we also included other environmental variables and observations. The 
measurements were done alternating shade cloths from low light to high light levels, sometimes starting and other times ending with $100 \% / 0 \%$ shade pair, otherwise in the order: $90 \%, 30 \%, 80 \%, 40 \%, 70 \%, 50 \%, 60 \%$ shade.

\subsection{5. $\mathrm{CH}_{4}$ flux measurements}

We collected $\mathrm{CH}_{4}$ samples from two collars at each well for three months. $\mathrm{CH}_{4}$ sample collection took place at the end of the wet season in May, at the middle of the dry season in July, and at the end of the dry season in August 2016. We prepared field $\mathrm{CH}_{4}$ standards in the MTU wetlands lab before going to Peru in order to test for any effects of sample transport. We filled nine $10 \mathrm{ml}$ exetainers with $10 \mathrm{ppm} \mathrm{CH}_{4}$ standard and another nine 10

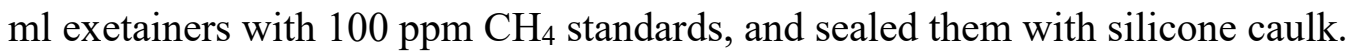

We used two closed $\mathrm{CH}_{4}$ chambers (diameter $40.6 \mathrm{~cm}$, height $31 \mathrm{~cm}$, volume $40,133 \mathrm{~cm}^{3}$ ) to collect gas samples (Hutchinson and Mosier 1981; Sanchez et al. 2017). $\mathrm{CH}_{4}$ chambers were placed on the same collars installed for $\mathrm{CO}_{2}$ measurements. Each chamber was equipped with a narrow vent tube (to minimize pressure differentials) and a fan. Samples were collected every fifteen minutes for a period of 45 minutes per collar using a $60 \mathrm{ml}$ syringe and needle. Gas samples were taken from the chamber's port without pumping the syringe to minimize changes in pressure inside the chamber. Prior to affixing the chamber, a sample of ambient air was taken over the vegetation of each collar to use later to correct fluxes. Ambient barometric pressure, humidity, temperature, dew point, soil moisture and soil temperature from a temperature probe inside the collar were recorded at the beginning and end of each measurement. We injected $\sim 20 \mathrm{ml}$ of gas 
in the exetainers to keep the vial pressurized. The syringe was flushed a 2-3 times before taking the next sample. Both chambers were used concurrently on neighboring collars. $\mathrm{CH}_{4}$ samples were analyzed in the laboratory using a flame ionization detector (FID) installed in a gas chromatograph (Varian CP- 3800, Palo Alto, CA, USA). We calculated a headspace correction to account for the gas dilution when taken samples from the chamber. The difference between the gas concentration with and without the headspace correction was negligible ( $0.02 \%$ on average). We used the ideal gas law equation to estimate $\mathrm{CH}_{4}$ fluxes:

$F_{C H_{4}}=\frac{\Delta C}{\Delta t} \times \frac{P}{1013} \times \frac{273}{273+T} \times \frac{16.043 \mathrm{~kg}}{22.4414 \mathrm{~m}^{3}} \times \frac{V c}{A c} \times \frac{\mathrm{mol}}{10^{6} \mathrm{\mu mol}} \times \frac{86400 \mathrm{~s}}{\text { day }} \times \frac{10^{6} \mathrm{mg}}{\mathrm{kg}} \quad$ Eq. 1.

Where: $F_{C H_{4}}$ is the $\mathrm{CH}_{4}$ efflux $\left(\mathrm{mg} \mathrm{m}^{-2} \mathrm{~d}^{-1}\right), \Delta \mathrm{C} / \Delta \mathrm{t}$ is the change in $\mathrm{CH}_{4}$ with time $(\mu \mathrm{mol}$ $\left.\mathrm{mol}^{-1} \mathrm{~s}^{-1}\right), \mathrm{P}$ is the barometric pressure (atm), $\mathrm{T}$ is the air temperature at soil surface $\left({ }^{\circ} \mathrm{C}\right)$, $16.043 \mathrm{~kg} / 22.4414 \mathrm{~m}^{3}$ are molar volume and ideal gas constants, $\mathrm{Vc}$ is the volume of the chamber when placed on top of the collar $\left(\mathrm{m}^{3}\right)$, and Ac is the area of the chamber $\left(\mathrm{m}^{2}\right)$.

\subsubsection{Vegetation survey}

We took pictures of each collar at the beginning, middle and end of the study period to look at plant communities and changes in plant growth. Each collar was examined visually to determine the plant communities inside of them. We visually estimated the percent cover of the cushion plants, non-cushion plants, as well as the percent bare ground for each collar. Then, we averaged the four collars around each well to estimate percent cushion plant cover, non-cushion plant cover, and bare ground cover 
around the well. We estimated the cushion plants contour and the percent cover of the non-cushion plants growing on top of them; therefore, it allows over $100 \%$ cover measurements.

We also estimated cushion plant production to relate with $\mathrm{C}$ fluxes. To estimate cushion plant production, we used the modified cranked wire method (Clymo 1970; Gunnarsson and Rydin 2000; Cooper et al. 2015). This method consists of $20 \mathrm{~cm}$ long metal wires with bristles installed in the cushion plants inside the collars. Every wire was inserted carefully in the cushions allowing $5 \mathrm{~cm}$ to extend vertically above the ground surface. Wires were installed on February 2016 and growth was measured in May, August and December 2016. In December 2016, we took 6 core samples of cushion plants near the collars in the reference area and 15 in the rewetted area. Cores were taken without altering their density and volume. Each core was $2 \mathrm{~cm}$ in diameter and $8 \mathrm{~cm}$ in length and included the live vegetation. We cut them into four $2 \mathrm{~cm}$ increment subsamples to relate organic carbon (OC) content with height gain. Samples were oven dried at $65{ }^{\circ} \mathrm{C}$ to a constant weight, then combusted in a muffle furnace to calculate $\mathrm{OM}$ content of each sample. Next, we followed the method described in Cooper et al. (2015) to estimate organic carbon (OC) production. To estimate production in plots with cranked wires but lacking core samples, we estimated a linear regression of height growth vs biomass for the cored plots, and used the average bulk density of the same cushion plant species in the same treatment to estimate biomass production. 


\subsection{Results}

\subsubsection{Water table}

Water table levels in the reference areas were relatively stable throughout the year, with a mean of $-4.6 \pm 0.35 \mathrm{~cm}$ depth during the wet season, and $-7.6 \pm 0.6 \mathrm{~cm}$ depth in the dry season (Fig. 5). The unrestored area had a mean water table level of $-108.5 \pm 3.13 \mathrm{~cm}$ depth in the wet season, and $-154 \pm 4.23 \mathrm{~cm}$ depth in the dry season. The rewetted area had an average of $-53.8 \pm 8.3 \mathrm{~cm}$ depth during the early wet season before the restoration, and an average of $-6.1 \pm 2.2 \mathrm{~cm}$ depth after the restoration for the same season. During the dry season, the rewetted area had an average of $-69.4 \pm 7.3 \mathrm{~cm}$ depth before the restoration and $-38 \pm 11.3 \mathrm{~cm}$ depth after the restoration.

\subsubsection{Vegetation survey and plant productivity}

We found 28 plant species in total, including cushion plants, graminoids, mosses, and other vascular plants. Reference and rewetted areas had the greatest number of species, and the unrestored area was less diverse (Table 1). We identified three species of cushion plants (Distichia muscoides Nees \& Meyen, Distichia sp., and Oreobolus obtusangulus Gaudich), graminoids including sedges (Carex sp.), herbaceous (Lachemilla sp.), grasses (Calamagrostis sp.), and mosses (Sphagnum spp.). We categorized them into two vegetation types for the purposes of this study: cushion plants and non-cushion plants (Table 2). 
Plant community composition changed across the water table gradient. The reference area had only $\sim 3 \%$ of bare ground and the highest percent cover of cushion plants (64.6\%), including both Distichia species as well as Oreobolus. We found an almost even percent cover of Oreobolus obtusangulus and non-cushion plants in the rewetted area ( $47.9 \%$ and $45.8 \%$ respectively), as well as $20 \%$ bare ground. The noncushion plants found were mostly sedges (Carex $s p$.) and grasses (Calamagrostis sp.). Lastly, we found a non-cushion plant community in the unrestored area, dominated by a trailing herb that is common in disturbed areas (Lachemilla orbiculata Ruiz \& Pav) and an invasive grass (Agrostis breviculmis Hitchc) with approximately 97\% plant cover and $\sim 3 \%$ bare ground.

Cushion plants in the reference area had higher plant production than in the rewetted area $(p=0.0054)$, with a mean plant growth of $0.463 \pm 0.11 \mathrm{~g} \mathrm{C} \mathrm{m}^{-2} \mathrm{hr}^{-1}$ in the reference area and $0.064 \pm 0.016 \mathrm{~g} \mathrm{C} \mathrm{m}^{-2} \mathrm{hr}^{-1}$ in the rewetted area. Within the reference area, Distichia and Oreobolus had no significant difference in growth $(p=0.308)$, Distichia had a mean growth of $0.639 \pm 0.21 \mathrm{~g} \mathrm{C} \mathrm{m}^{-2} \mathrm{hr}^{-1}$ and Oreobulus $0.362 \pm 0.13 \mathrm{~g} \mathrm{C}$ $\mathrm{m}^{-2} \mathrm{hr}^{-1}$. Oreobolus in the reference site had a greater production than in the rewetted area $(p=0.028)$, with a mean plant growth of $0.064 \pm 0.016 \mathrm{~g} \mathrm{C} \mathrm{m}^{-2} \mathrm{hr}^{-1}$ in the rewetted area and $0.362 \pm 0.13 \mathrm{~g} \mathrm{C} \mathrm{m}^{-2} \mathrm{hr}^{-1}$ in the reference area.

\subsection{3. $\mathrm{CO}_{2}$ fluxes}

$\mathrm{CO}_{2}$ fluxes varied by season and among treatments (Fig. 6, Table 3). We use the sign convention in which negative values signify ecosystem release of $\mathrm{CO}_{2}$, and positive 
values signify ecosystem uptake of $\mathrm{CO}_{2}$. During the wet season, NEE was higher than in the dry season in all treatments (Table 3). ER was stable in the reference sites, and decreased slightly in the rewetted areas during the wet season. ER in the unrestored area had a very different behavior than other treatments, increasing greatly during the wet season. GPP tended to increase during the wet season in the unrestored and reference areas, however, it remained stable in the rewetted area. The greatest ER and GPP fluxes were registered in the unrestored area during both the wet and dry season (Table 3). ER and GPP were greater in the reference area than in the rewetted area for both seasons.

Throughout the study period, all treatments had a mean daytime $\mathrm{CO}_{2}$ uptake by the ecosystem (i.e., positive NEE), except for two months in the unrestored area. The reference areas had the greatest ecosystem uptake of $1.07 \pm 0.06 \mathrm{~g} \mathrm{CO}_{2} \mathrm{~m}^{-2} \mathrm{hr}^{-1}$, followed by the rewetted area with $0.86 \pm 0.04 \mathrm{~g} \mathrm{CO}_{2} \mathrm{~m}^{-2} \mathrm{hr}^{-1}$, and lastly the unrestored area with $0.76 \pm 0.11 \mathrm{~g} \mathrm{CO}_{2} \mathrm{~m}^{-2} \mathrm{hr}^{-1}$. In the rewetted area, NEE increased when water table levels were closer to the soil surface, approaching the reference area values (Fig. 7A).

We did simple regression analysis between water table depth and fluxes for each month, and found that the correlation between ER and water table is significant for several months in the wet season, but not the dry season (Table 4). We plotted the slope of ER:WT over time (Fig. 8) and noticed that as the dry season progressed, the slope of this relationship decreased.

Because these are instantaneous measurements, without considering nighttime respiration, we developed a GPP:ER ratio plot in order to have a better estimate of what a 
24-hour basis carbon balance will look like. A value of 2 for the ratio is considered to be a rough approximation of a zero net carbon balance on a 24 hour bases. As expected, water table had a strong positive relationship with the GPP:ER ratio. Carbon balance becomes more positive as water table increases, especially in the rewetted area (Figure 9). Within the reference treatment, we found high variation in the GPP:ER ratio, and the rewetted treatment shows a similar behavior when water table level is above $\sim 20 \mathrm{~cm}$ depth. The unrestored area did not show a significant increase in its carbon balance with changes in water table.

\subsubsection{Light response curves}

For the pooled data from all dates, light levels were a strong predictor of NEE, explaining over $30 \%$ of the variation in rates, with rates saturating ( $95 \%$ of maximum) at $\sim 1900$ and an overall light compensation point of $\sim 300 \mu \mathrm{mol} \mathrm{CO}_{2} \mathrm{~m}^{-2} \mathrm{~s}^{-1}$ (Fig 10A). We couldn't estimate a light saturation point (LSP) from the light response curve experiments, because we did not have enough points at the high end of the curve (Figure 10B); however, we could estimate the light compensation point (LCP) using the NEE values for each collar. We found that LCP was lowest in the reference and rewetted areas with higher water table levels, while the unrestored area with lower water table levels had the highest light compensation point (Figure 11). 


\subsection{5. $\mathrm{CH}_{4}$ fluxes}

We measured very low $\mathrm{CH}_{4}$ fluxes overall, averaging $2.76 \pm 1.06 \mathrm{mg} \mathrm{CH}_{4} \mathrm{~m}^{-2}$ day $^{-1}$ across all dates and treatments (Figure 12). However, there appears to be a water table threshold at approximately $-10 \mathrm{~cm}$ above which $\mathrm{CH}_{4}$ fluxes increase. Below $-10 \mathrm{~cm}$ water table depth, the average $\mathrm{CH}_{4}$ flux is $-0.07 \pm 0.784 \mathrm{mg} \mathrm{CH}_{4} \mathrm{~m}^{-2}$ day $^{-1}$ and above $-10 \mathrm{~cm}$ water table depth, the average $\mathrm{CH}_{4}$ flux is $5.58 \pm 9.18 \mathrm{mg} \mathrm{CH}_{4} \mathrm{~m}^{-2}$ day $^{-1}$.

\subsection{Discussion}

\subsubsection{Hydrologically undisturbed sites}

Even though there are large differences in precipitation amounts between the wet and dry seasons, the water table levels in the reference sites were stable. Average water table levels in the wet season were $4.6 \mathrm{~cm}$ below the soil surface and only dropped to an average of $7.6 \mathrm{~cm}$ below the soil surface during the dry season. The stable water table levels, in combination with a moderately high $\mathrm{pH} \sim 5.8$ and specific conductivity of 146 $\mu \mathrm{S} \mathrm{cm}^{-1}$ indicates that these are groundwater fed peatlands, or fens. Fens are the most common peatland type in mountains with bogs being limited to very high rainfall areas (Cooper et al. 2012). These results are similar to other studies that have found that undisturbed mountain fens have perennially stable water table levels (Cooper et al. 2012).

Our $\mathrm{CO}_{2}$ values are the first measured in a mountain peatland in the Puna ecosystem. The reference $\mathrm{CO}_{2}$ flux averages for NEE, GPP, and ER values were NEE, $1.05 \mathrm{~g} \mathrm{CO}_{2} \mathrm{~m}^{-2} \mathrm{hr}^{-1}, 1.82 \mathrm{~g} \mathrm{CO}_{2} \mathrm{~m}^{-2} \mathrm{hr}^{-1},-0.76 \mathrm{~g} \mathrm{CO}_{2} \mathrm{~m}^{-2} \mathrm{hr}^{-1}$, respectively. Our values 
are slightly greater than reference conditions measured in an Ecuadoran Paramo cushion plant fen where Sánchez et al. (2017) measured an average NEE, GPP, and ER rate of $0.69 \mathrm{~g} \mathrm{CO}_{2} \mathrm{~m}^{-2} \mathrm{hr}^{-1}, 1.35 \mathrm{~g} \mathrm{CO}_{2} \mathrm{~m}^{-2} \mathrm{hr}^{-1},-0.66 \mathrm{~g} \mathrm{CO}_{2} \mathrm{~m}^{-2} \mathrm{hr}^{-1}$, respectively. Such differences might be caused by the difference in climatic conditions and vegetation communities. However, our values are lower compared to mountain sedge fens in Colorado. The Colorado sedge fens had greater NEE and GPP $\left(1.74 \mathrm{~g} \mathrm{CO}_{2} \mathrm{~m}^{-2} \mathrm{hr}^{-1}\right.$ and $\left.2.85 \mathrm{~g} \mathrm{CO}_{2} \mathrm{~m}^{-2} \mathrm{hr}^{-1}\right)$, but lower ER (-0.63 $\left.\mathrm{g} \mathrm{CO}_{2} \mathrm{~m}^{-2} \mathrm{hr}^{-1}\right)$ (Schimelpfenig et al. 2014). The $\mathrm{CO}_{2}$ values are also very similar to Sphagnum moss poor fen in Michigan that had an average NEE, GPP, and ER rate of $1.05 \mathrm{~g} \mathrm{CO}_{2} \mathrm{~m}^{-2} \mathrm{hr}^{-1}, 1.82 \mathrm{~g} \mathrm{CO}_{2} \mathrm{~m}^{-2} \mathrm{hr}^{-1},-0.75 \mathrm{~g} \mathrm{CO}_{2}$ $\mathrm{m}^{-2} \mathrm{hr}^{-1}$, respectively (Ballantyne et al. 2014). Although our GPP values are lower than those found for sedge fens, the growing season for temperate peatlands lasts for about 7 months, whereas plants in the tropics grow all year long, making them productive all year.

$\mathrm{CH}_{4}$ emissions increased with high water table levels, confirming our hypothesis. $\mathrm{CH}_{4}$ emissions in the wet undisturbed areas were very low $\left(7.06 \pm 3.42 \mathrm{mg} \mathrm{CH}_{4} \mathrm{~m}^{-2}\right.$ day${ }^{1}$ ), comparable to what Sánchez et al. (2017) found in a cushion peatland in Ecuador (8.1 $\left.\pm 1.17 \mathrm{mg} \mathrm{CH}_{4} \mathrm{~m}^{-2} \mathrm{day}^{-1}\right)$. These rates are lower than those reported for northern temperate and boreal peatlands (Turetsky et al. 2014; Abdalla et al. 2016; Strack et al. 2016) (Figure 13), but higher than another study conducted by Fritz et al. (2011) in a cushion peatland in Patagonia where they found zero $\mathrm{CH}_{4}$ emissions. Low $\mathrm{CH}_{4}$ fluxes might be explained by vegetation communities present in the area, especially cushion 
plants and sedges, which have deep roots that transport oxygen deep in the soil, making it available to oxidize the $\mathrm{CH}_{4}$ produced by Archaea (Fritz et al. 2011).

\subsubsection{Response to water table drawdown}

Carbon cycling in the very dry unrestored area responded differently to water table levels compared to the reference and rewetted areas. Although NEE was relatively unresponsive to water table in all treatments, the slope of the water table- $\mathrm{CO}_{2}$ flux relationship in the unrestored treatment differed from the other two in both GPP and ER. These differences might be related to the divergence in plant communities, specifically the absence of the cushion plants in the unrestored treatment. Surprisingly, ER in the unrestored treatment had a negative relationship to water table depth, possibly because dry season drought suppressed plant and microbial respiration. Although this phenomenon has not been explored previously in mountain peatlands, a study conducted in a forested peatland in Alaska discovered that microbial activities decreased up to $50 \%$ after a prolonged drought (Allison and Treseder 2008).

Our findings indicate that the reference sites have a more positive carbon balance than the unrestored treatment, as indicated by the GPP:ER ratio and the light compensation point analysis. Although our results are based on daytime flux rates, we expect that the low GPP:ER ratios of the unrestored area might indicate that this area is a net carbon source when considered on a 24-hour basis. 
Although the effect of restoration was complicated in this study by the timing of the wet season, our results indicate that rewetting increased NEE and the ability to store carbon to near reference conditions. This was also found in Colorado mountain fens that were restored as NEE increased from -1.3 to $-2.2 \mathrm{~g} \mathrm{CO}_{2} \mathrm{~m}^{-2} \mathrm{hr}^{-1}$ after ditch plugs were installed (Schimelpfenig et al. 2014). This indicates that hydrologic restoration in the Andes have the potential to reinstate carbon cycling to more reference conditions.

The steep threshold in the water table- $\mathrm{CH}_{4}$ relationship deviates from the pattern shown in a global analysis of $\mathrm{CH}_{4}$ emissions from lowland peatlands (Turetsky et al. 2014). This could be because dry conditions during the $\mathrm{CH}_{4}$ measurement period (MayAugust 2016) which led to drying of the surface of the peat, favoring methanotrophy over methanogenesis. Alternatively, cushion plants have deep aerenchymatous roots that transport oxygen to the deep peat and could also stimulated $\mathrm{CH}_{4}$ oxidation. Consistent with this hypothesis, Fritz et al. (2011) found zero emissions of $\mathrm{CH}_{4}$ at a water table depth of $\sim-12 \mathrm{~cm}$.

\subsection{Conclusions}

This is the first study to measure $\mathrm{CO}_{2}$ and $\mathrm{CH}_{4}$ emissions in a mountain peatland in Peru and the second one in South America, providing novel insights about these ecologically important and unexplored ecosystems.

Effects on $\mathrm{CO}_{2}$ fluxes from water table differed across the drainage gradient. Moderately drained areas responded similarly to the reference areas when water table 
levels were high, whereas the highly drained area had a strikingly different behavior, where ecosystem respiration increased as the peat went from low moisture content to wetter conditions. We suggest a 24-hour measurement study to determine whether these undisturbed ecosystems are $\mathrm{C}$ sources.

The low observed $\mathrm{CH}_{4}$ emissions were consistent with what another study in the Ecuadorian Andean peatland found. Even though areas with high water table levels exhibit $\mathrm{CH}_{4}$ emissions, values are lower than what is found in peatlands in the boreal and temperate regions. This could mean that as a $\mathrm{CO}_{2} \operatorname{sink}$ and small $\mathrm{CH}_{4}$ source, these ecosystems are likely to reduce greenhouse gas from the atmosphere and have a cooling effect in the long term. 


\subsection{References}

Abdalla, Mohamed, Astley Hastings, Jaak Truu, Mikk Espenberg, Ülo Mander, and Pete Smith. "Emissions of $\mathrm{CH}_{4}$ from northern peatlands: a review of management impacts and implications for future management options." Ecology and evolution 6, no. 19 (2016): 7080-7102.

Allison, S.D., Treseder, K.K. (2008). Warming and drying suppress microbial activity and carbon cycling in boreal forest soils. Global change biology 14, no. 12: 28982909.

Ballantyne DM, Hribljan JA, Pypker TG, Chimner RA (2014) Long-term water table manipulations alter peatland gaseous carbon fluxes in Northern Michigan. Wetlands Ecology and Management 22:35-47.

Benavides JC (2014) The effect of drainage on organic matter accumulation and plant communities of high-altitude peatlands in the Colombian tropical Andes. Mires Peat $15: 1-15$

Billings WD, Mooney HA (1968) the Ecology of Arctic and Alpine Plants. Biol Rev $43: 481-529$.

Bradley, R.S., Vuille, M, Diaz, H.F., Vergara, W. (2006). Threats to Water Supplies in the Tropical Andes. Science 23: 1755-1756.

Bubier JL, Crill PM, Moore TR, et al (1998) Seasonal patterns and controls on net 
ecosystem $\mathrm{CO}_{2}$ exchange in a boreal peatland complex. Global Biogeochem Cycles 12:703-714 .

Bubier JL, Gaytri B, Moore TR, et al (2003) Spatial and Temporal Variability in Growing-Season Net Ecosystem $\mathrm{CO}_{2}$ Exchange at a Large Peatland in Ontario, Canada. Ecosystems 6:353-367 .

Bubier JL, Moore TR, Bellisario L, et al (1995) Ecological controls on $\mathrm{CH}_{4}$ emissions from a northern peatland complex in the zone of discontinuous permafrost, Global Biogeochemical Cycles 9:455-470.

Byers AC (2000) Contemporary Landscape Change in the Huascarán National Park and Buffer Zone, Cordillera Blanca, Peru. Mt Res Dev 20:52-63 .

Chanton JP (2005) The effect of gas transport on the isotope signature of $\mathrm{CH}_{4}$ in wetlands. Organic Geochemistry 36:753-768

Chimner RA, Cooper DJ (2003a) Influence of water table levels on $\mathrm{CO}_{2}$ emissions in a Colorado subalpine fen: An in situ microcosm study. Soil Biol Biochem 35:345351.

Chimner RA, Cooper DJ (2003b) Carbon dynamics of pristine and hydrologically modified fens in the southern Rocky Mountains. Canadian Journal of Botany 81:477-491.Chimner RA, Cooper DJ, Wurster FC, Rochefort L (2017) An overview of peatland restoration in North America: where are we after 25 years? Restoration Ecology 25:283-292. 
Chimner RA, Karberg JM (2008) Long-term carbon accumulation in two tropical mountain peatlands, Andes Mountains, Ecuador. Mires Peat 3:1-10

Clymo RS (1970) The Growth of Sphagnum : Methods of Measurement. British Ecological Society 58:13-49.

Clymo RS (1987) Peatland ecology. Science Progress. Oxford, 71 593-614. 593-614

Cooper DJ, Chimner RA, Merritt DM (2012) Mountain Wetlands of North America. In: Wetland Habitats of North America: Ecology and Conservation Concerns (eds: Batzer D. and Balswin A.). University of California Press, Berkeley, CA.

Cooper DJ, Kaczynski K, Slayback D, Yager K (2015) Growth and Organic Carbon Production in Peatlands Dominated by, Bolivia, South America. Arctic, Antarctic, and Alpine Research 47:505-510.

Cooper DJ, Wolf EC, Colson C, et al (2010) Alpine Peatlands of the Andes, Cajamarca, Peru. Arctic, Antarctic, and Alpine Research 42:19-33.

Dullo BW, Grootjans AP, Roelofs JGM, et al (2017) Radial oxygen loss by the cushion plant Eriocaulon schimperi prevents $\mathrm{CH}_{4}$ emissions from an East-African mountain mire. Plant Biology 19:736-741.

Earle LR, Warner BG, Aravena R (2003) Rapid development of an unusual peataccumulating ecosystem in the Chilean Altiplano. Quaternary Research 59:2-11.

Fritz C, Pancotto VA, Elzenga JTM, et al (2011) Zero $\mathrm{CH}_{4}$ emission bogs: Extreme rhizosphere oxygenation by cushion plants in Patagonia. New Phytologist 190:398408. 
Gatis N, Luscombe DJ, Grand-Clement E, et al (2016) The effect of drainage ditches on vegetation diversity and $\mathrm{CO}_{2}$ fluxes in a Molinia caerulea-dominated peatland. Ecohydrology 9:407-420.

Gunnarsson U, Rydin H (2000) Nitrogen fertilization reduces Sphagnum production in bog communities. New Phytologist 147:527-537.

Hribljan JA, Cooper DJ, Sueltenfuss J, et al (2015) Carbon storage and long-term rate of accumulation in high-altitude Andean peatlands of Bolivia. Mires and Peat 15:1-14

Hribljan JA, Suárez E, Heckman KA, et al (2016) Peatland carbon stocks and accumulation rates in the Ecuadorian páramo. Wetlands Ecology and Management 24:113-127.

Hutchinson GL, Mosier AR (1981) Improved Soil Cover Method for Field Measurement of Nitrous Oxide Fluxes. Soil Science Society of America Journal 45:311.

Liblik LK, Moore TR, Bubier JL, Robinson SD (1997) $\mathrm{CH}_{4}$ emissions from wetlands in the zone of discontinuous permafrost:Forst Simpson, Northwest Territories, Canada. Global Biochemical Cycles 11:485-494.

Luan J, Liu S, Wu J, et al (2018) The transient shift of driving environmental factors of $\mathrm{CO}_{2}$ and $\mathrm{CH}_{4}$ fluxes in Tibetan peatlands before and after hydrological restoration. Agricultural and Forest Meteorology 250-251:138-146.

Millones J. (1982) Patterns of Land Use and Associated Environmental Problems of the Central Andes: An Integrated Summary. Mountain Research and Development, 2 (1), 49-61. 
Moore TIMR, Bubier JL, Frolking SE, et al (2002) Plant biomass and production and CO 2 exchange in an ombrotrophic bog. Journal of Ecology 1:25-36.Moore T., Knowles R. (1989) The influence of water table levels on $\mathrm{CH}_{4}$ and $\mathrm{CO}_{2}$ emissions from peatland soils. Canadian Journal of Soil Science 69:33-38.

Nykänen H, Alm J, Silvola J, et al (1998) $\mathrm{CH}_{4}$ fluxes on boreal peatlands of different fertility and the effect of long-term experimental lowering of the water table on flux rates. Global Biogeochemical Cycles 12:53-69.

Oechel, W. et. al. (1998) The effects of water table manipulation and elevated temperature on the nt $\mathrm{CO}_{2}$ flux of wet sedge tundra ecosystems. Global Change Biology 77-90.

Page S, Hosciło A, Wösten H, et al (2009) Restoration ecology of lowland tropical peatlands in Southeast Asia: Current knowledge and future research directions. Ecosystems 12:888-905.

Preston D, Fairbairn J, Paniagua N, et al (2003) Grazing and Environmental Change on the Tarija Altiplano, Bolivia. Mountaint Research and Development 23:141-148.

Salvador F, Monerris J, Rochefort L (2014) Peatlands of the Peruvian Puna ecoregion: types, characteristics and disturbance. Mires and Peat 15:1-17

Samaniego P, Monzier M, Robin C, Hall ML (1998) Late Holocene eruptive activity at Nevado Cayambe volcano, Ecuador. Bulletin of Volcanology 59:451-459. Sanchez M, Chimner RA, Hribljan J, et al (2017) $\mathrm{CO}_{2}$ and $\mathrm{CH}_{4}$ fluxes in grazed and undisturbed mountain peatlands in the Ecuadorian Andes. Mires and Peat 19:1-18. 
Schimelpfenig DW, Cooper DJ, and Chimner RA (2014) Effectiveness of ditch blockage for restoring hydrologic and soil processes in mountain peatlands. Restoration Ecology 22:257-265

Schütz H, Seiler W, Conrad R (1990) Influence of Soil Temperature on $\mathrm{CH}_{4}$ Emission from Rice Paddy Fields. Biogeochemistry 11:77-95

Shannon RD, White JR (1994) A three-year study of controls on $\mathrm{CH}_{4}$ emissions from two Michigan peatlands. Biogeochemistry 27:35-60

Silvola J, Alm J, Ahlhom U, et al (2010) $\mathrm{CO}_{2}$ Fluxes from Peat in Boreal Mires under Varying Temperature and Moisture Conditions. Journal of Ecology 84:219-228.

Strack M, Cagampan J, Fard GH, et al (2016) Controls on plot-scale growing season $\mathrm{CO}_{2}$ and $\mathrm{CH}_{4}$ fluxes in restored peatlands : Do they differ from unrestored and natural sites? Mires and Peat 17:1-18.Turetsky M (2002) Current disturbance and the diminishing peatland carbon sink. Geophysical Research Letters 29:1526.

Turetsky, Merritt R., Agnieszka Kotowska, Jill Bubier, Nancy B. Dise, Patrick Crill, Ed RC Hornibrook, Kari Minkkinen et al. (2014). A synthesis of $\mathrm{CH}_{4}$ emissions from 71 northern, temperate, and subtropical wetlands. Global change biology 20, no. 7 : 2183-2197.Vasander H, Kettunen A (2006) Carbon in Boreal Peatlands. Boreal Peatland Ecosystems 188:165-194.

Vilímek V, Zapata ML, Klimeš J, et al (2005) Influence of glacial retreat on natural hazards of the Palcacocha Lake area, Peru. Landslides 2:107-115.

Whiting J, Bartlett S, Fan S, Bakwin, P, Wofsy, Steven C (1992) Biosphere/Atmosphere 
$\mathrm{CO}_{2}$ Exchange in Tundra Ecosystems: Community Characteristics and Relationships With Multispectral Surface Reflectance. Journal of Geophysical Research 97:16,671-16,680.Wilson S, Blain D, Couwenberg J, et al (2016) Greenhouse gas emission factors associated with rewetting of organic soils. Mires and Peat 17:1-28. 


\subsection{Figures}

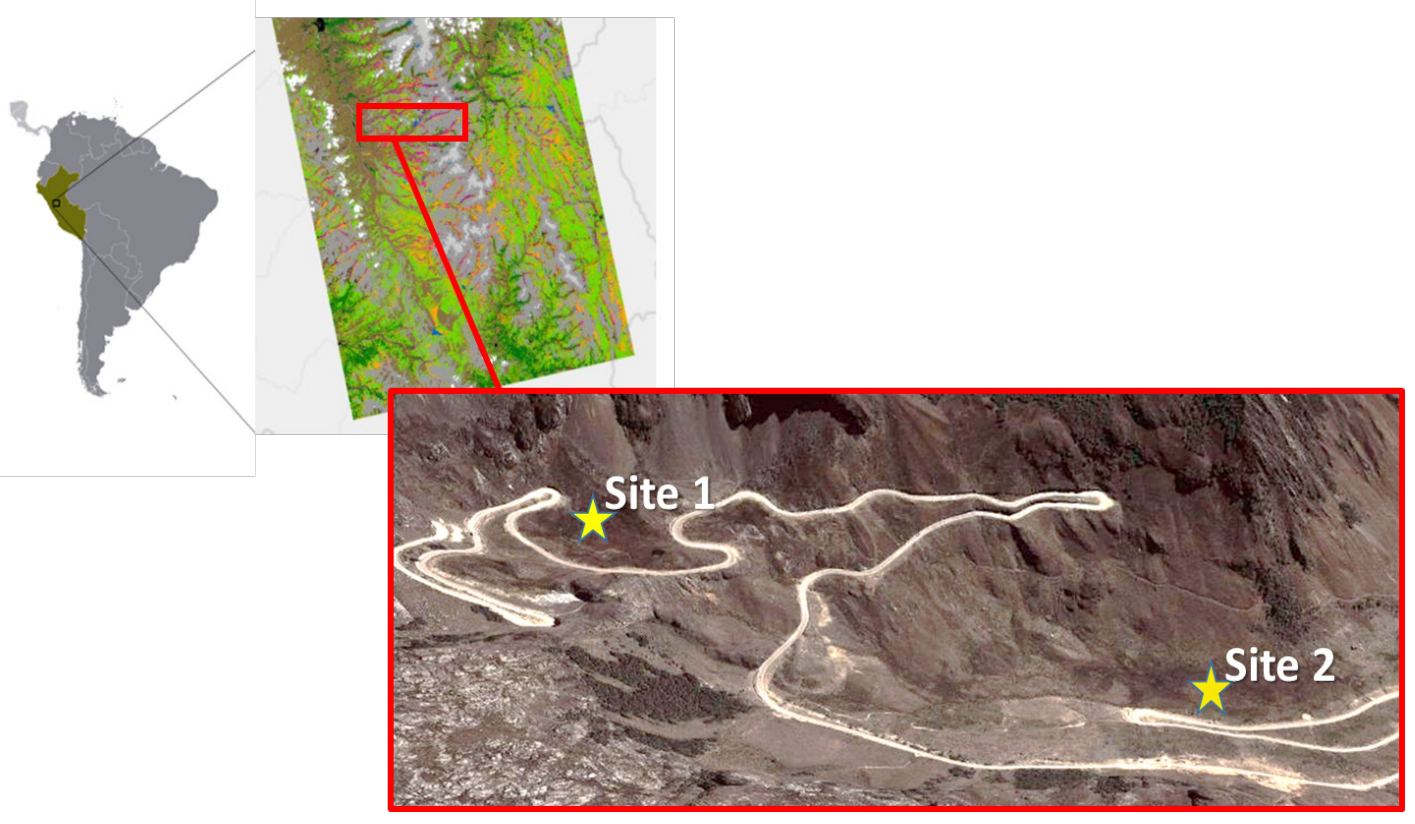

Figure 1. Location of study site in Huascaran National Park (yellow marks), located in the central Andes of Peru. 


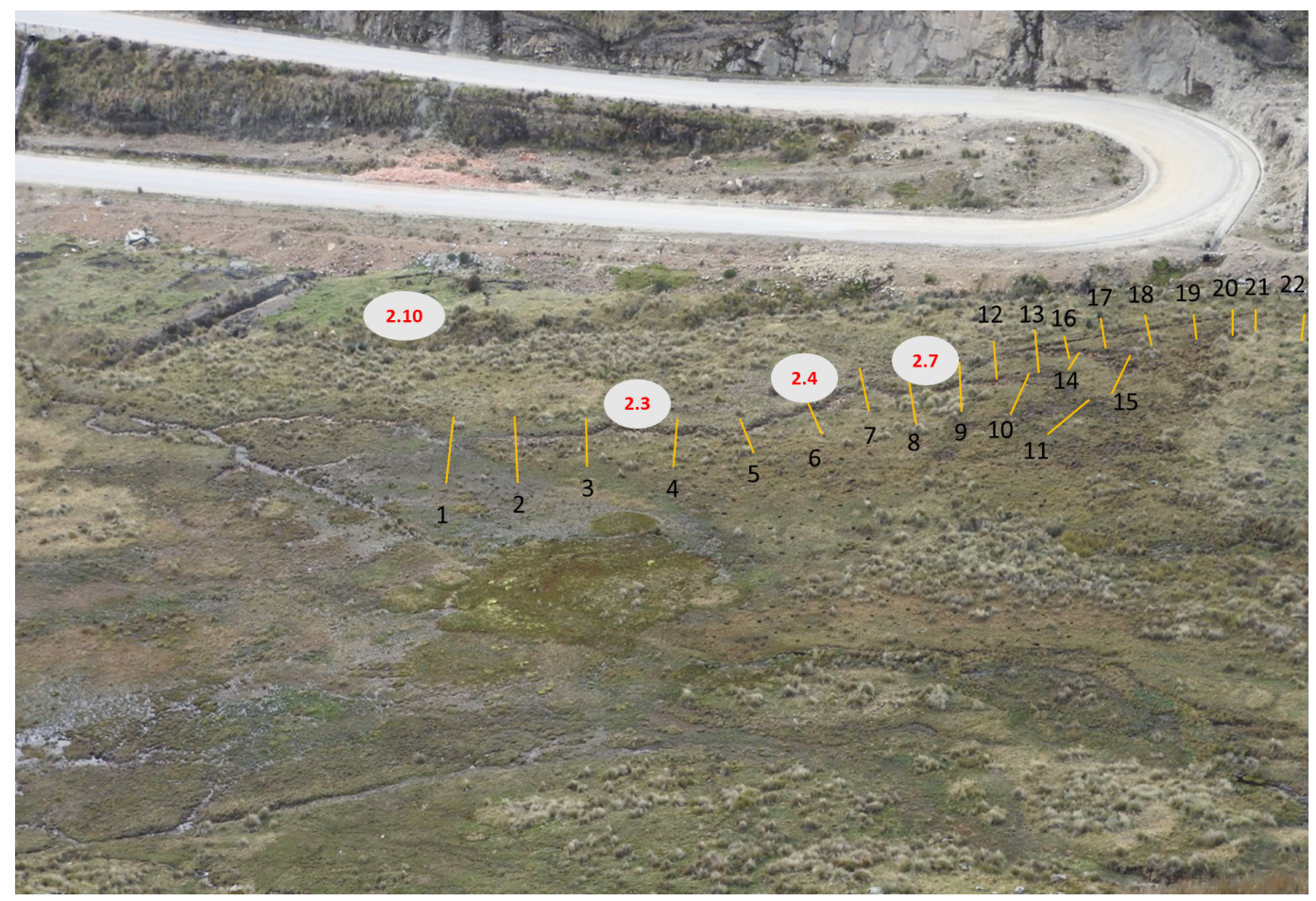

Figure 2. Ditch in site 2 with check dams (yellow lines) and location of wells (red numbers inside white ovals) in the rewetted area, and unrestored area (well 2.10). 


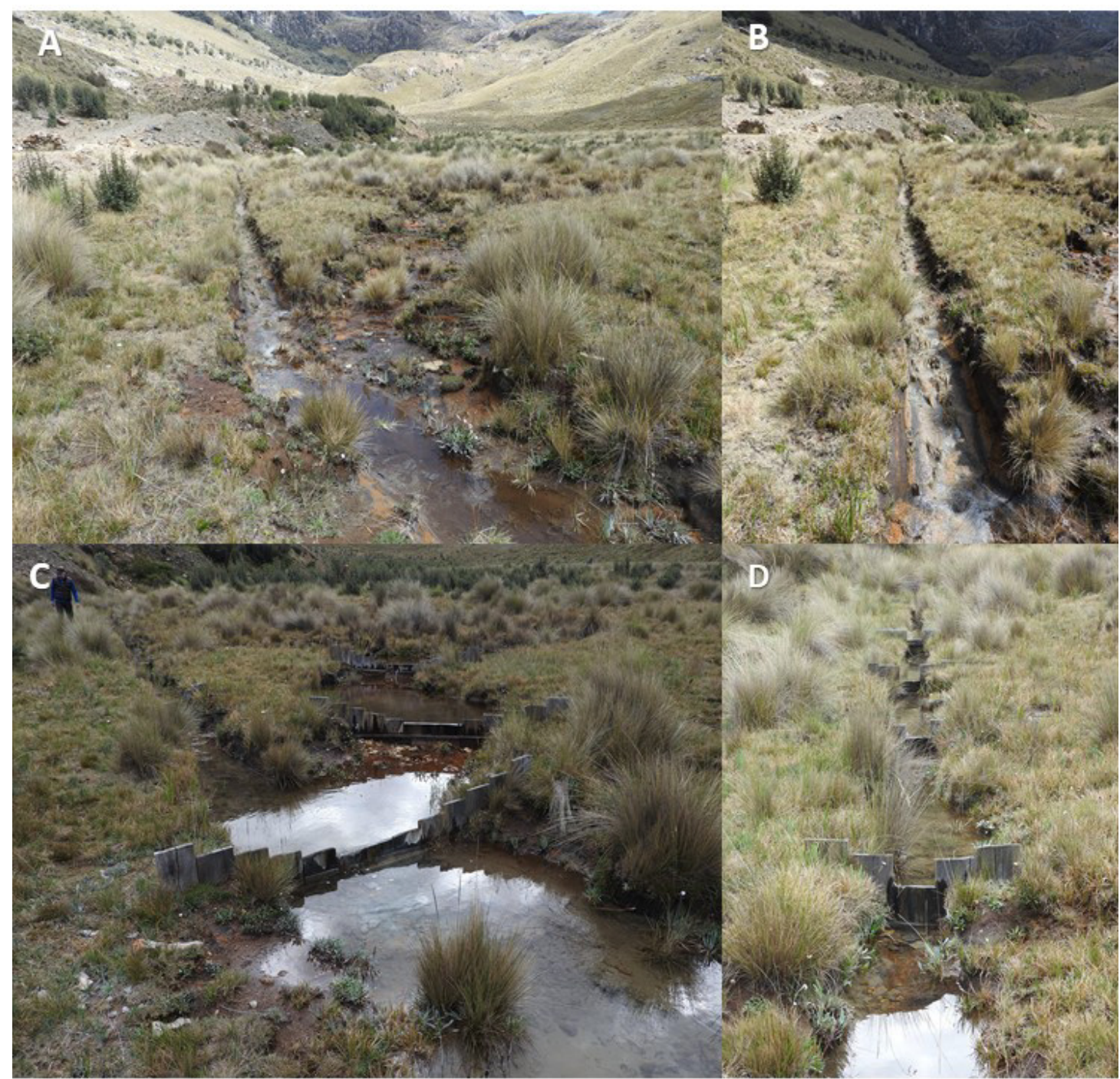

Figure 3. Ditched areas in paramo peatland. Two ditch sections shown before (A and B) and after (C and D) ditch blocking. 


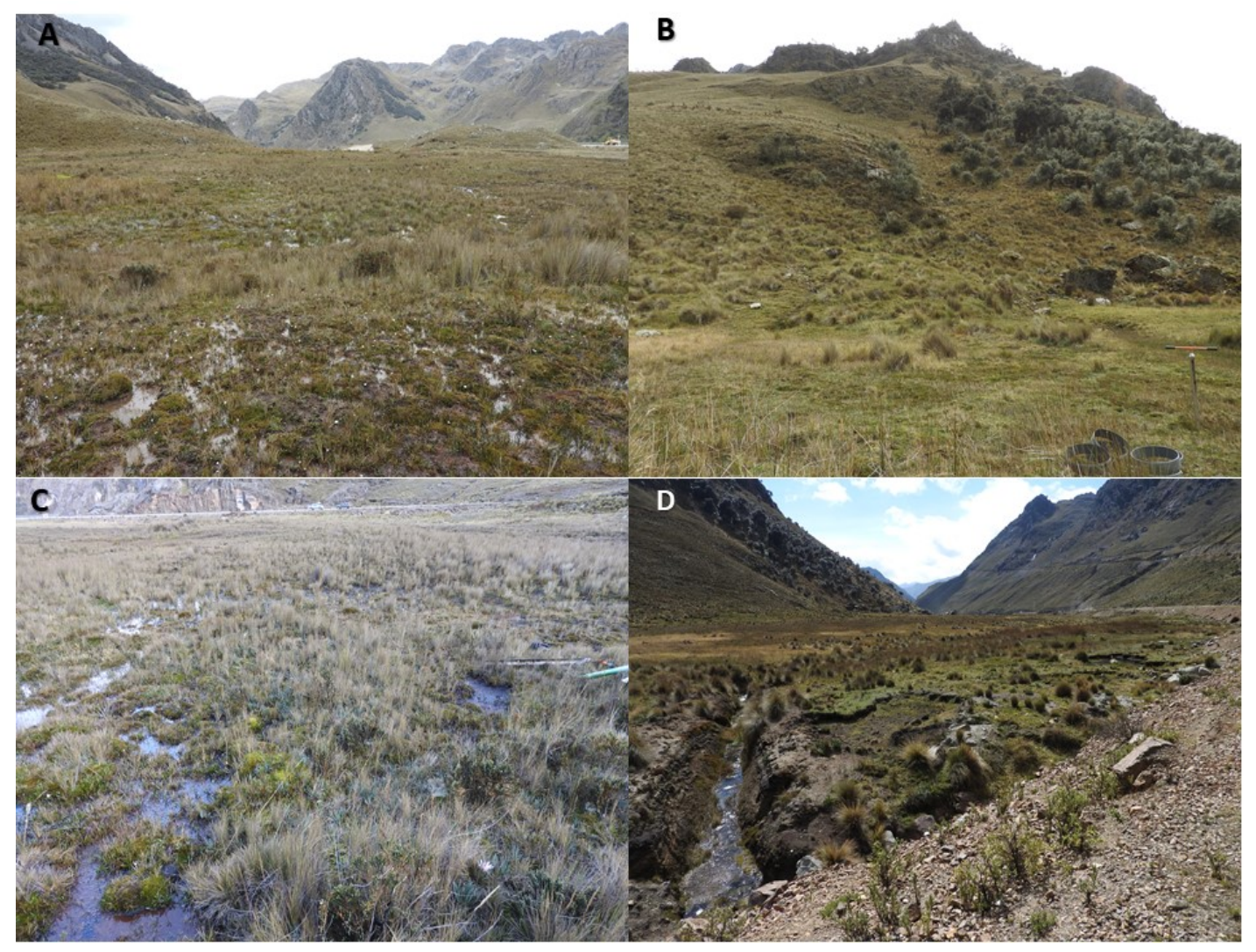

Figure 4. Peatlands study sites in Huascaran National Park, Peru. A) shows reference area at site 1. B) and C) show reference area at site 2. D) shows a ditched and degraded part near the unrestored area. 


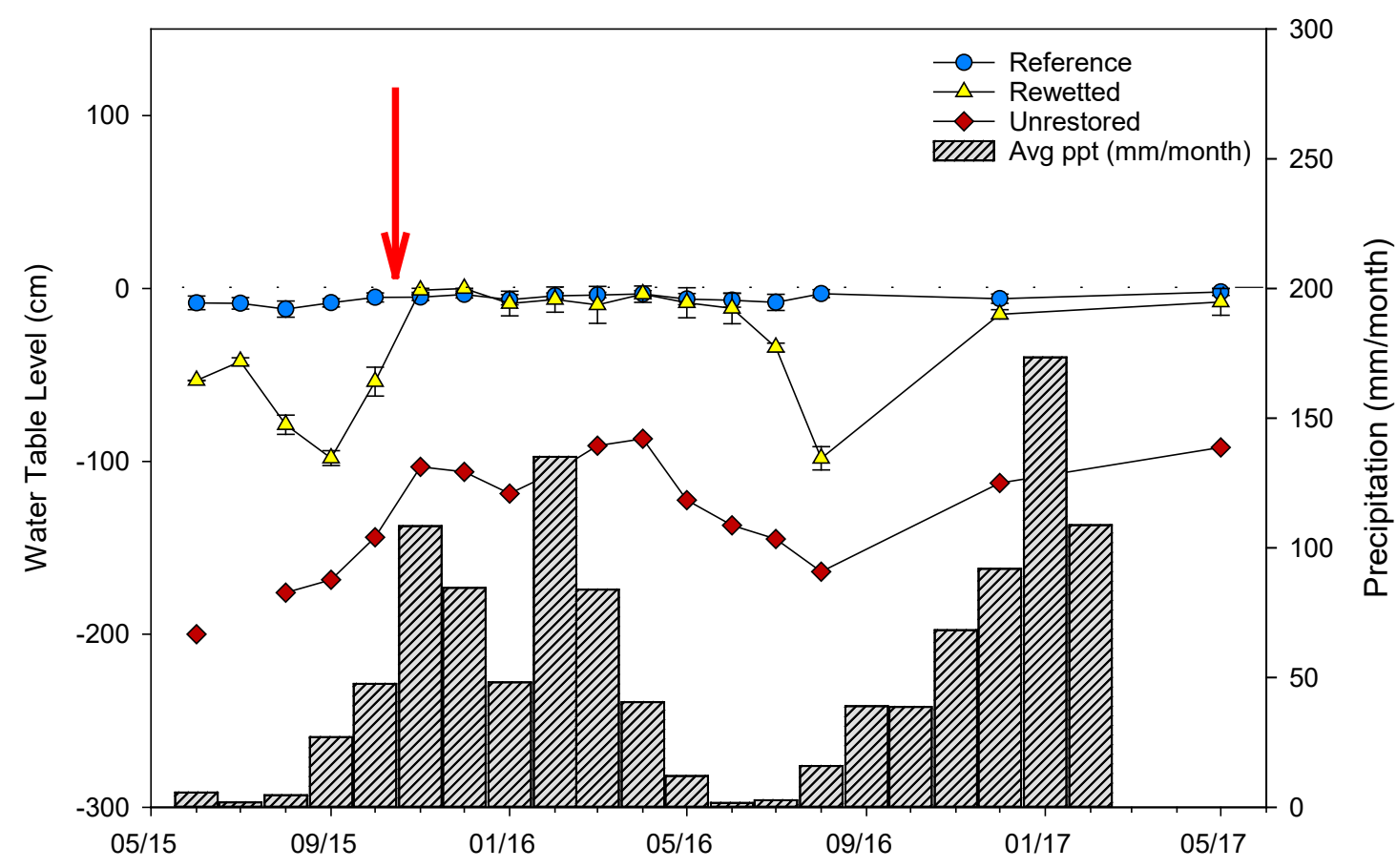

Figure 5. Average precipitation ( $\mathrm{mm} / \mathrm{month}$ ) from four meteorological stations near the study area - Milpo, Chavin, Recuay, and Santiago Antunez de Mayolo (grey bars) - and the fluctuation in water table levels from the different treatments (lines) during the study period. Water table is averaged by treatment per month, error bars show standard error (SE). Note that the reference area is an average of both sites (1 and 2). Red arrow shows when the check dams were installed (October 2015). 

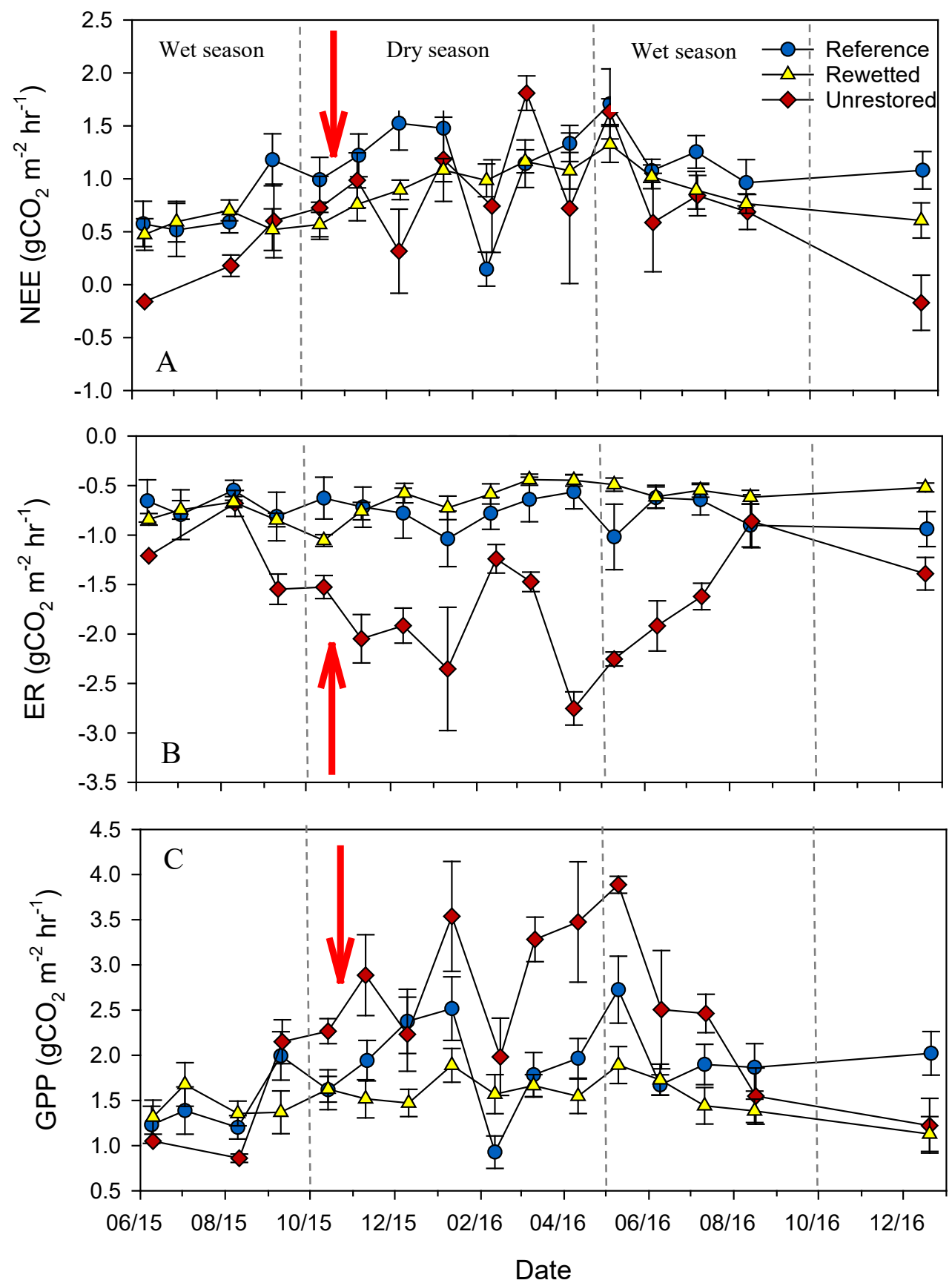

Figure 6. Changes in $\mathrm{CO}_{2}$ fluxes in the Tambillos valley during the wet and dry seasons by water table treatment. A) shows net ecosystem exchange (NEE), B) shows ecosystem respiration (ER), and C) shows gross primary production (GPP). Symbols are averages of fluxes by treatment, error bars show standard error (SE). Red arrow indicates when the restoration began. 

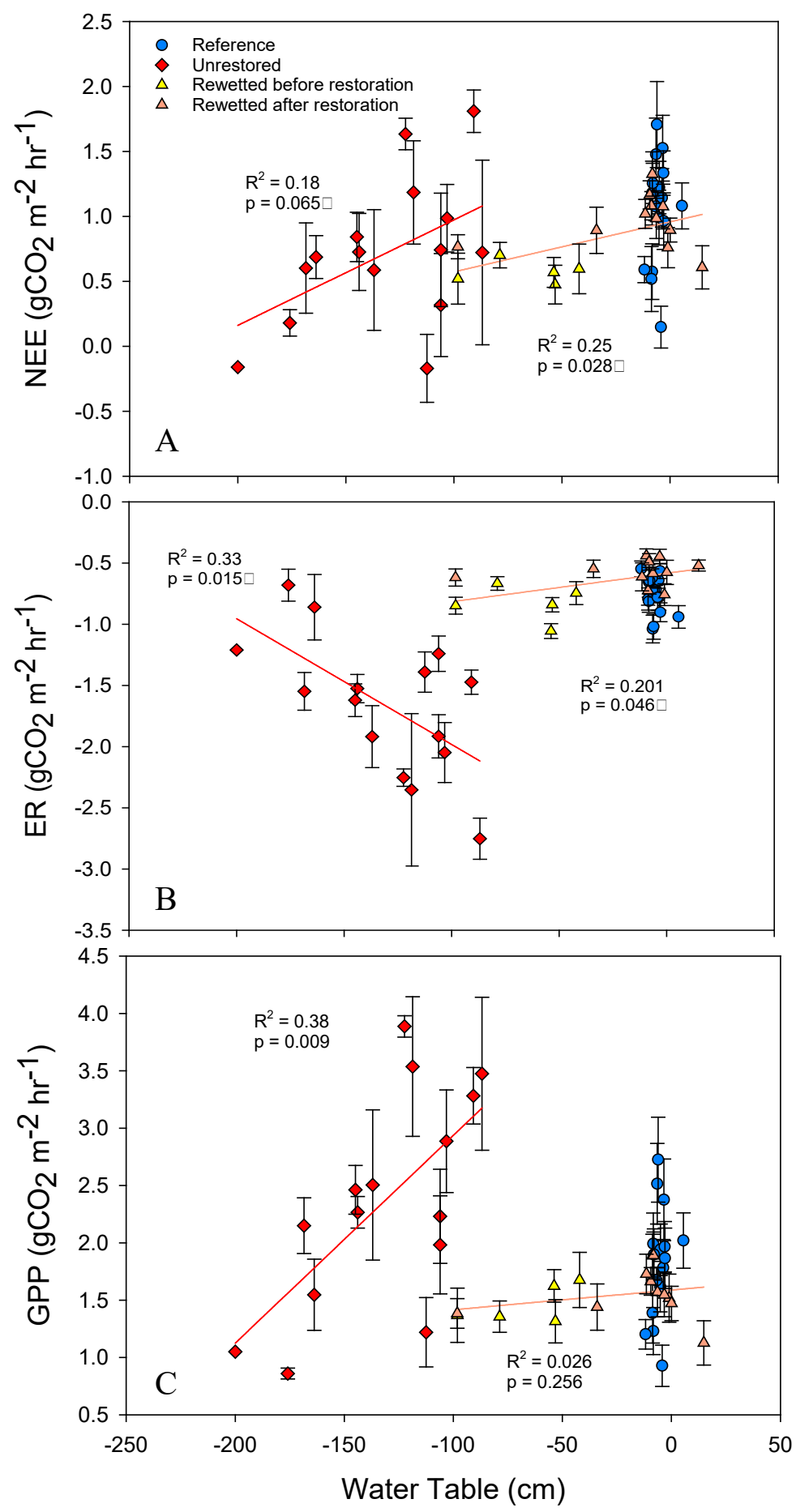

Figure 7. Daytime $\mathrm{CO}_{2}$ fluxes fluctuate by treatment in relation to water table: A) NEE, B) ER, and C) GPP. Means are averages of fluxes by treatment and error bars represent standard error (SE). A regression line shows the relationship between $\mathrm{CO}_{2}$ fluxes and water table for the unrestored (red line) and rewetted (orange line) treatments. 


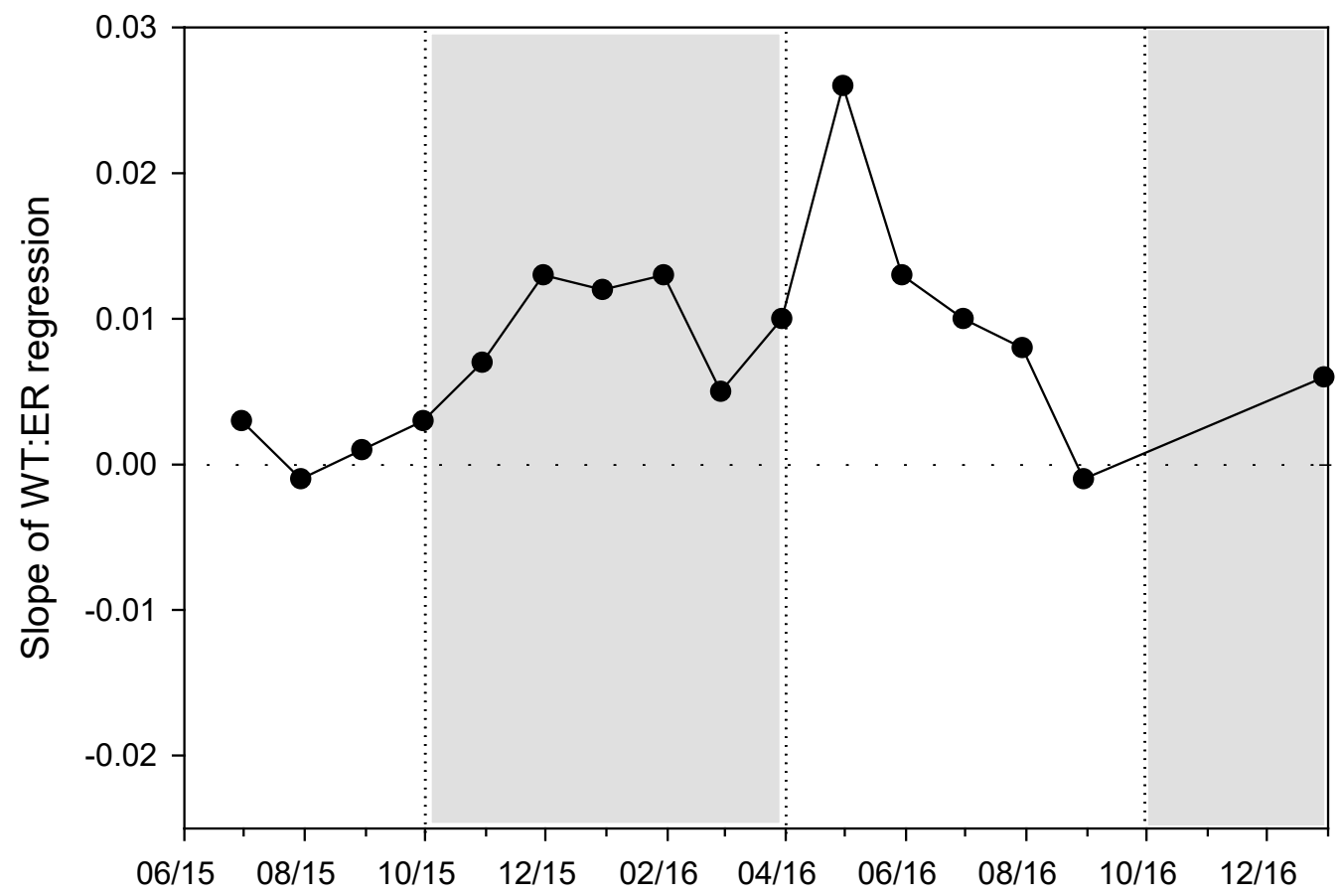

Figure 8. Slope of WT:ER regression by date. Areas in grey correspond to the wet season, and white to the dry season. 


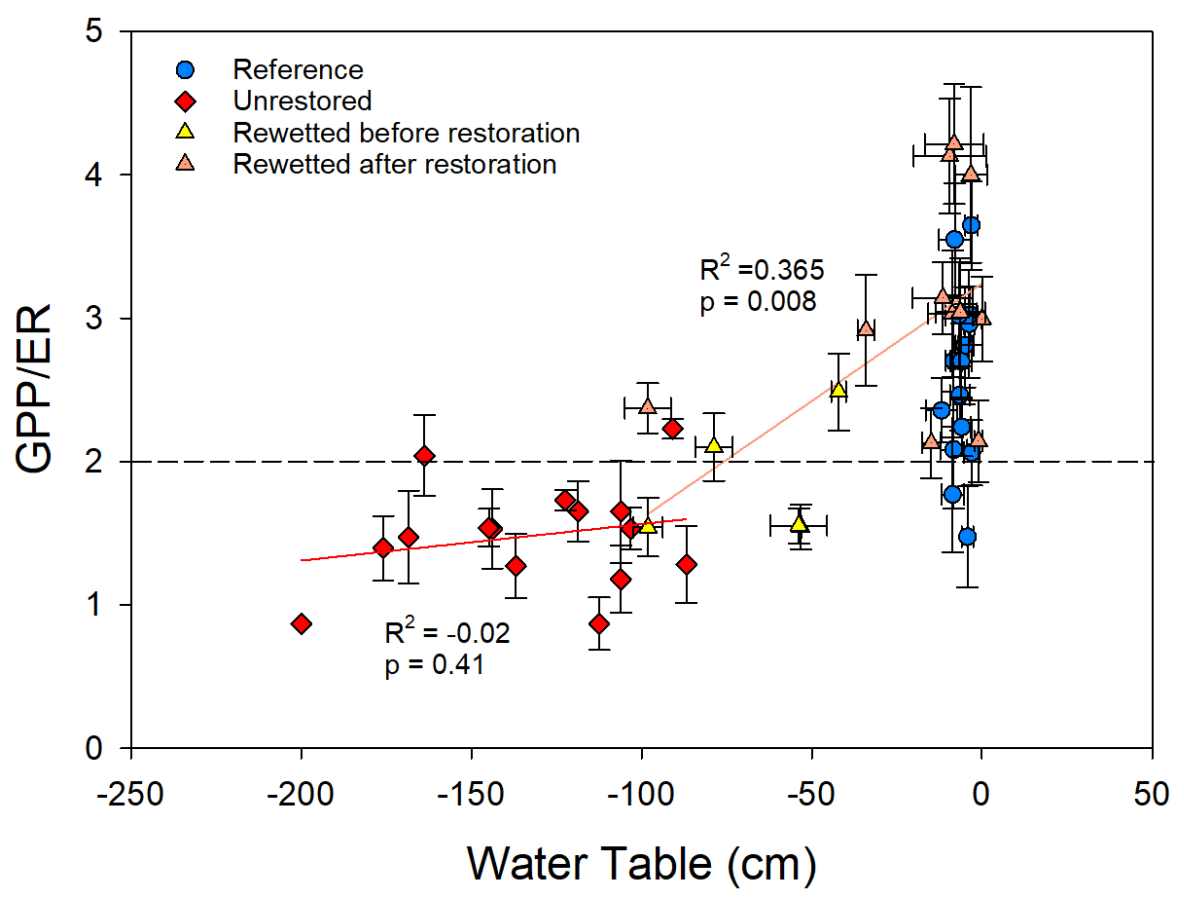

Figure 9. Changes in instantaneous daytime GPP/ER ratio at different water table levels by treatment. Blue circles represent the averaged fluxes of the reference areas, yellow triangles the rewetted area before the restoration and the orange triangles the rewetted area after the restoration. Red diamonds represent the unrestored area. Error bars represent standard error (SE). Simple regression lines for the unrestored (red line), and rewetted (orange line) treatments. 

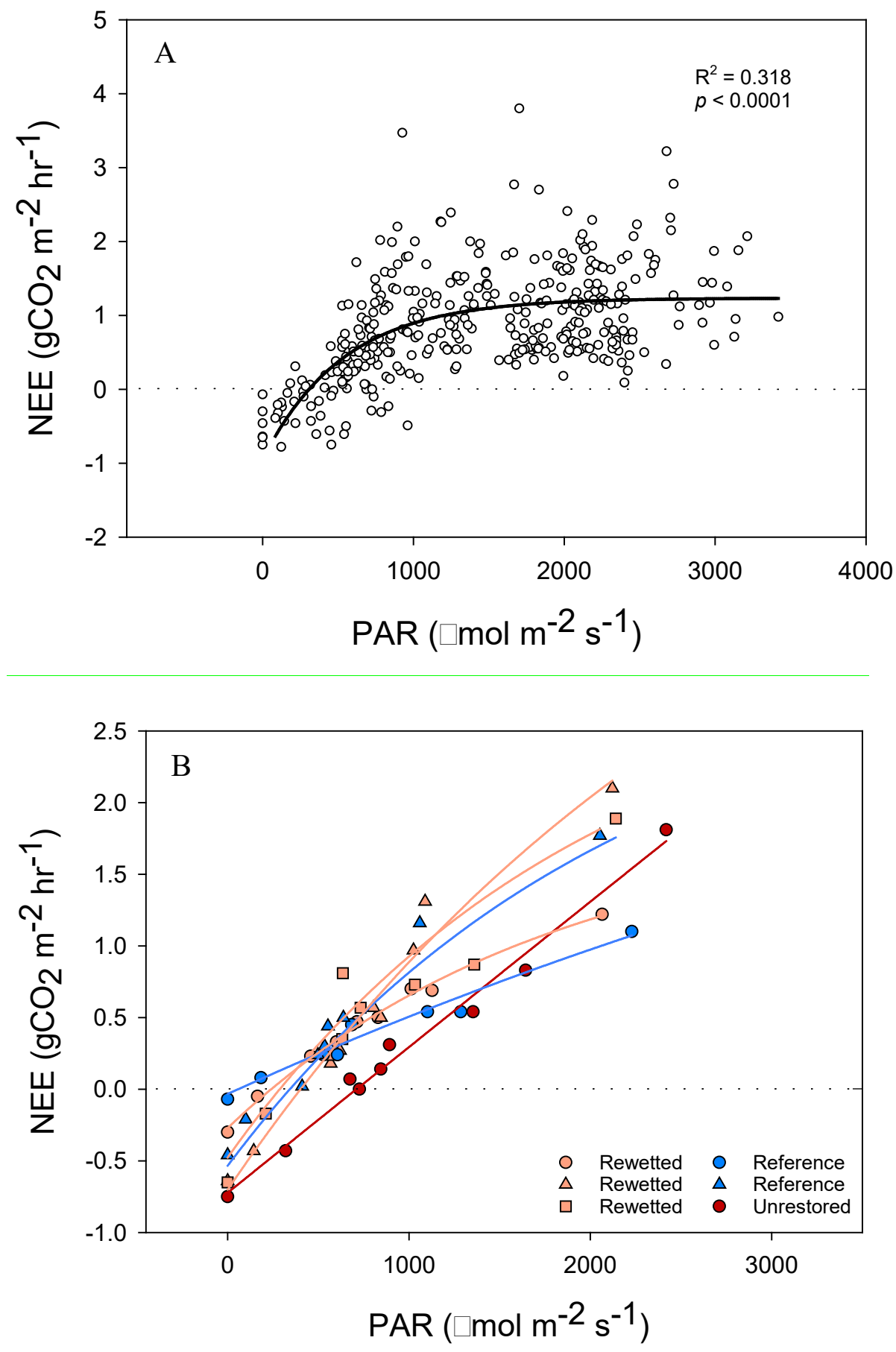

Figure 10. Peatland net ecosystem exchange of $\mathrm{CO}_{2}$ in response to light. A) Light response curve for net ecosystem exchange of $\mathrm{CO}_{2}$ for all plots during the study period. B) Light response curves of each of the collars assessed in the light curve experiment for three months in the dry season. 


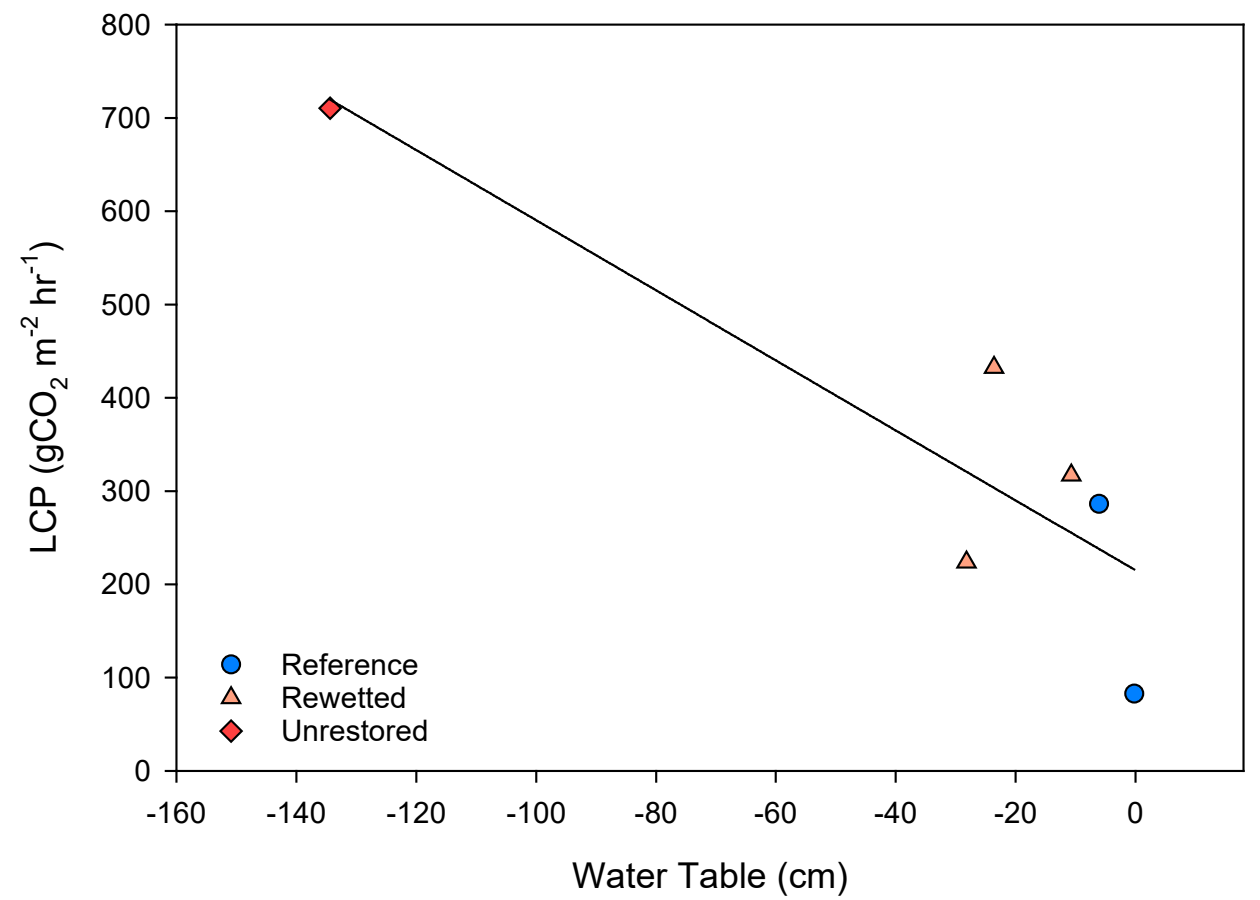

Figure 11. Light compensation point for net ecosystem exchange of $\mathrm{CO}_{2}$ estimated using the collars assessed in the light response curve experiment by water table at the time of measurement. 


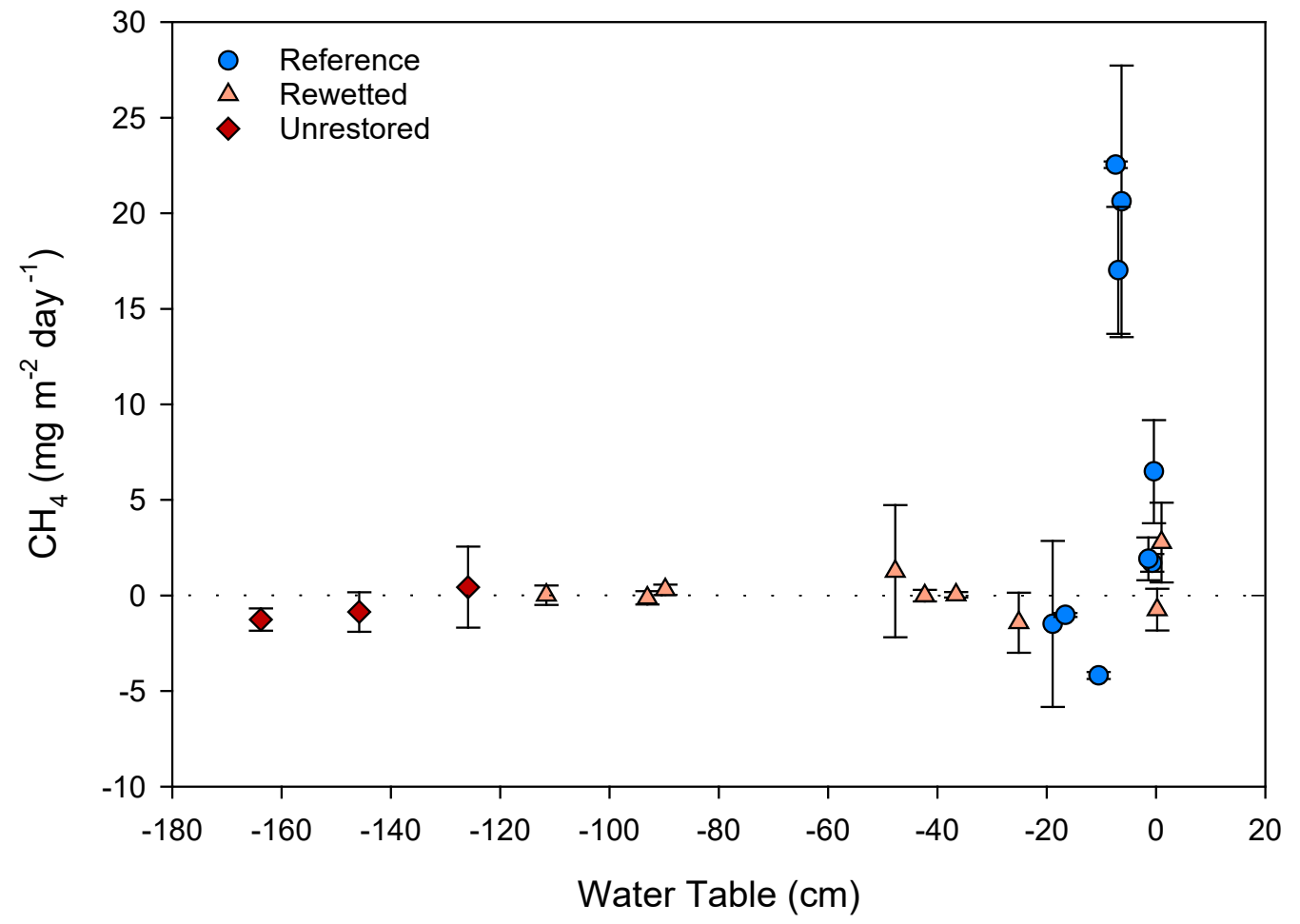

Figure 12. $\mathrm{CH}_{4}$ fluxes by water table from May 2016, July 2016 and August 2016 in all treatments in a peatland carbon cycling experiment in the páramo of Peru. 


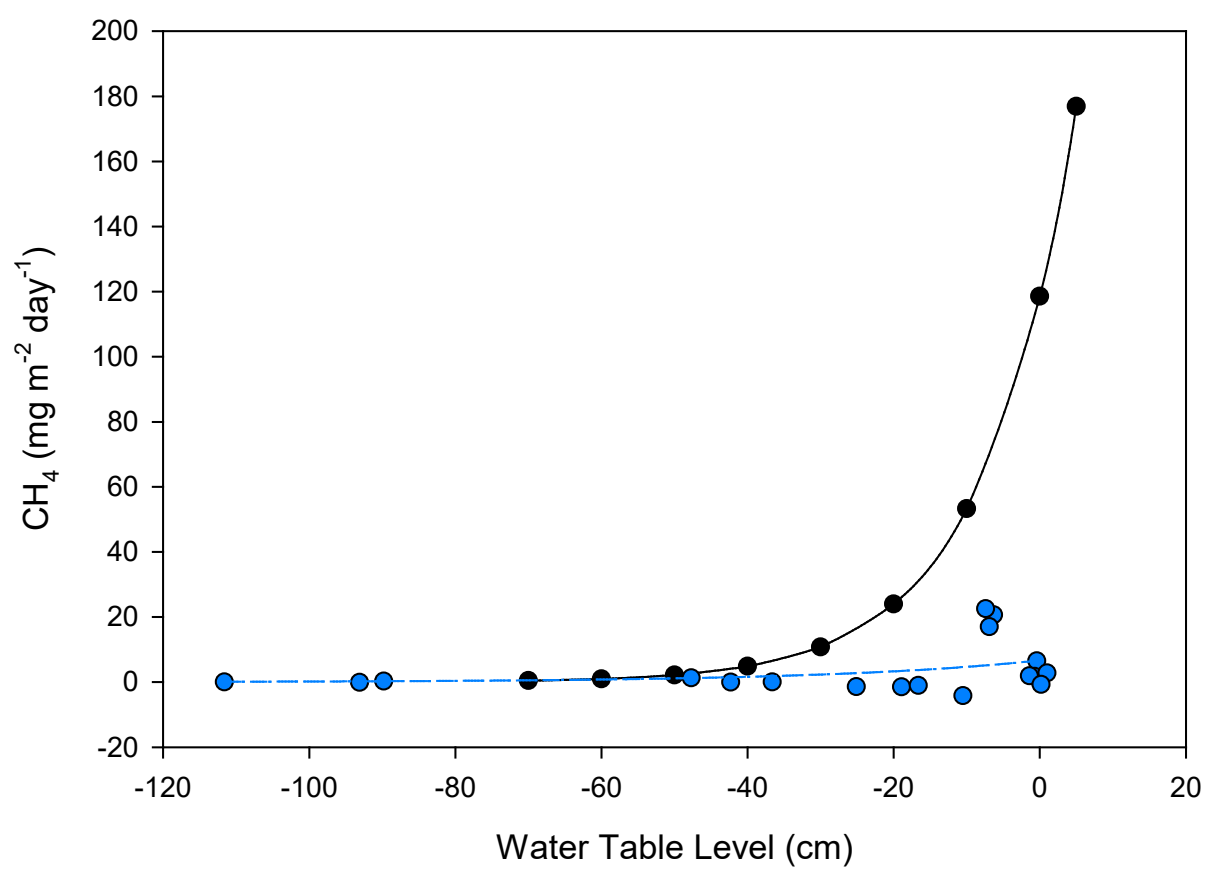

Figure 13. Comparison of best fit for water table effect on $\mathrm{CH}_{4}$ emissions in temperate and boreal peatlands (Abdalla et al. 2016; black filled circles) and cushion dominated mountain peatland in Peru by water table gradient (this study; blue filled circles). 


\subsection{Tables}

Table 1. Average water table; species richness; percent cushion, non-cushion, and bare ground cover by well. Note that cover can sum to $>100 \%$.

\begin{tabular}{|c|c|c|c|c|c|c|c|}
\hline Well \# & $\begin{array}{c}\text { Water } \\
\text { table } \\
(\mathrm{cm}) \mathrm{BR}\end{array}$ & $\begin{array}{l}\text { Species } \\
\text { Richness }\end{array}$ & $\begin{array}{l}\text { Distichia } \\
\text { sp. } \\
(\% \text { cover })\end{array}$ & $\begin{array}{c}\text { Oreobulus } \\
\text { obtusangulus } \\
\text { (\% cover) }\end{array}$ & $\begin{array}{c}\text { Total } \\
\text { cushion } \\
(\% \\
\text { cover }) \\
\end{array}$ & $\begin{array}{c}\text { Non- } \\
\text { cushion } \\
(\% \\
\text { cover }) \\
\end{array}$ & $\begin{array}{c}\text { Bare } \\
\text { ground } \\
(\%) \text { cover }\end{array}$ \\
\hline $\begin{array}{l}1.1 \\
\text { Reference }\end{array}$ & $\begin{array}{c}-3.8 \pm \\
1.13 \\
\end{array}$ & 6 & 22.5 & $13.75 \pm 8.98$ & $\begin{array}{c}36.25 \pm \\
11.34 \\
\end{array}$ & $\begin{array}{c}80 \pm \\
13.54 \\
\end{array}$ & $10 \pm 7.07$ \\
\hline $\begin{array}{l}2.1 \\
\text { Reference }\end{array}$ & $\begin{array}{l}-8.3 \pm \\
2.04\end{array}$ & 7 & $\begin{array}{l}67.5 \pm \\
13.15\end{array}$ & $20 \pm 12.25$ & $\begin{array}{c}87.5 \pm \\
12.24\end{array}$ & $\begin{array}{c}50 \pm \\
12.25\end{array}$ & 0 \\
\hline $\begin{array}{l}2.2 \\
\text { Reference }\end{array}$ & $\begin{array}{c}-14.0 \pm \\
14.13\end{array}$ & 10 & 0 & $70 \pm 10.8$ & $\begin{array}{c}70 \pm \\
14.14\end{array}$ & $\begin{array}{c}52.5 \pm \\
9.46\end{array}$ & 0 \\
\hline $\begin{array}{l}2.7 \\
\text { Rewetted }\end{array}$ & $\begin{array}{c}-56.9 \pm \\
10.26\end{array}$ & 10 & 0 & $48.75 \pm 19.4$ & $\begin{array}{c}50 \pm \\
12.87\end{array}$ & $\begin{array}{c}60 \pm \\
10.31\end{array}$ & $\begin{array}{c}18.75 \pm \\
6.57\end{array}$ \\
\hline $\begin{array}{l}2.4 \\
\text { Rewetted }\end{array}$ & $\begin{array}{c}-68.1 \pm \\
9.59\end{array}$ & 7 & 0 & $45 \pm 2.89$ & $45 \pm 8.61$ & $30 \pm 0$ & $37.5 \pm 2.5$ \\
\hline $\begin{array}{l}2.3 \\
\text { Rewetted }\end{array}$ & $\begin{array}{c}-68.3 \pm \\
9.57\end{array}$ & 8 & 0 & $50 \pm 17.8$ & $\begin{array}{c}48.75 \pm \\
12.54\end{array}$ & $\begin{array}{l}47.5 \pm \\
13.54\end{array}$ & $\begin{array}{c}6.25 \pm \\
1.25\end{array}$ \\
\hline $\begin{array}{l}2.10 \\
\text { Unrestored }\end{array}$ & $\begin{array}{c}-172.1 \pm \\
10.33\end{array}$ & 4 & 0 & 0 & 0 & $\begin{array}{c}97.5 \pm \\
2.5\end{array}$ & $2.5 \pm 2.5$ \\
\hline
\end{tabular}


Table 2. The most abundant species in all treatments ( $>10 \%$ cover). The presence of each species in a well is marked with an X.

\begin{tabular}{|l|l|c|c|c|c|c|c|c|}
\hline \multicolumn{1}{|c|}{ Species } & $\begin{array}{c}\text { Functional } \\
\text { type }\end{array}$ & $\begin{array}{c}1.1 \\
(\text { Ref. })\end{array}$ & $\begin{array}{c}2.1 \\
(\text { Ref. })\end{array}$ & $\begin{array}{c}2.2 \\
(\text { Ref. })\end{array}$ & $\begin{array}{c}2.3 \\
(\text { Rew. })\end{array}$ & $\begin{array}{c}2.4 \\
(\text { Rew. })\end{array}$ & $\begin{array}{c}2.7 \\
\text { (Rew. })\end{array}$ & $\begin{array}{c}2.10 \\
\text { (Unresto. })\end{array}$ \\
\hline Distichia spp. & Cushion & $\mathrm{X}$ & $\mathrm{X}$ & & & & & \\
\hline Sphagnum spp. & Moss & $\mathrm{X}$ & $\mathrm{X}$ & & & & & \\
\hline Zameioscirpus sp. & Graminoid & & $\mathrm{X}$ & & & & & \\
\hline $\begin{array}{l}\text { Oreobolus } \\
\text { obtusangulus }\end{array}$ & Cushion & $\mathrm{X}$ & $\mathrm{X}$ & $\mathrm{X}$ & $\mathrm{X}$ & $\mathrm{X}$ & $\mathrm{X}$ & \\
\hline $\begin{array}{l}\text { Oritrophium } \\
\text { limnophilum }\end{array}$ & Herbaceous & $\mathrm{X}$ & $\mathrm{X}$ & $\mathrm{X}$ & $\mathrm{X}$ & $\mathrm{X}$ & $\mathrm{X}$ & \\
\hline $\begin{array}{l}\text { Calamagrostis } \\
\text { spp. }\end{array}$ & Graminoid & $\mathrm{X}$ & $\mathrm{X}$ & $\mathrm{X}$ & $\mathrm{X}$ & $\mathrm{X}$ & $\mathrm{X}$ & $\mathrm{X}$ \\
\hline Plantago tubulosa & Cushion & & $\mathrm{X}$ & $\mathrm{X}$ & $\mathrm{X}$ & $\mathrm{X}$ & & \\
\hline Carex spp. & Graminoid & & & $\mathrm{X}$ & $\mathrm{X}$ & $\mathrm{X}$ & $\mathrm{X}$ & \\
\hline $\begin{array}{l}\text { Werneria } \\
\text { nubigena }\end{array}$ & Herbaceous & & & $\mathrm{X}$ & $\mathrm{X}$ & $\mathrm{X}$ & $\mathrm{X}$ & \\
\hline Lachemilla spp. & Herbaceous & & & & & & & $\mathrm{X}$ \\
\hline $\begin{array}{l}\text { Agrostis } \\
\text { breviculmis }\end{array}$ & Graminoid & & & & & & & $\mathrm{X}$ \\
\hline
\end{tabular}


Table 3. Mean $\pm \mathrm{SE}$ daytime of $\mathrm{CO}_{2}$ fluxes by treatment in the wet and dry season.

\begin{tabular}{|c|l|l|l|l|c|}
\hline Season & Treatment & \multicolumn{1}{|c|}{$\begin{array}{c}\text { NEE } \\
\left(\mathrm{g} \mathrm{CO}_{2} \mathrm{~m}^{-2} \mathrm{hr}^{-1}\right)\end{array}$} & $\begin{array}{c}\text { ER } \\
\left(\mathrm{g} \mathrm{CO}_{2} \mathrm{~m}^{-2} \mathrm{hr}^{-1}\right)\end{array}$ & $\begin{array}{c}\text { GPP } \\
\left(\mathrm{g} \mathrm{CO}_{2} \mathrm{~m}^{-2} \mathrm{hr}^{-1}\right)\end{array}$ & GPP/ER \\
\hline \multirow{2}{*}{ Wet } & Reference & $1.116 \pm 0.084$ & $-0.762 \pm 0.033$ & $1.888 \pm 0.100$ & $2.66 \pm 0.121$ \\
\cline { 2 - 6 } & Rewetted & $0.896 \pm 0.052$ & $-0.643 \pm 0.035$ & $1.543 \pm 0.065$ & $2.84 \pm 0.151$ \\
\cline { 2 - 6 } & Unrestored & $0.786 \pm 0.165$ & $-1.837 \pm 0.122$ & $2.613 \pm 0.203$ & $1.49 \pm 0.103$ \\
\hline \multirow{2}{*}{ Dry } & Reference & $1.022 \pm 0.084$ & $-0.761 \pm 0.035$ & $1.810 \pm 0.101$ & $2.58 \pm 0.133$ \\
\cline { 2 - 6 } & Rewetted & $0.813 \pm 0.06$ & $-0.658 \pm 0.030$ & $1.524 \pm 0.071$ & $2.59 \pm 0.142$ \\
\cline { 2 - 6 } & Unrestored & $0.719 \pm 0.133$ & $-1.469 \pm 0.128$ & $2.188 \pm 0.223$ & $1.55 \pm 0.97$ \\
\hline
\end{tabular}




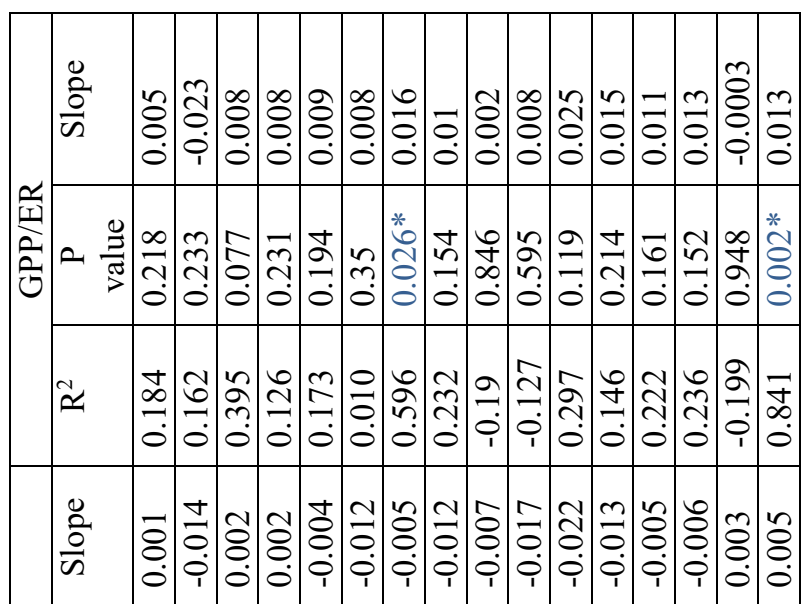

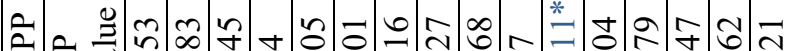

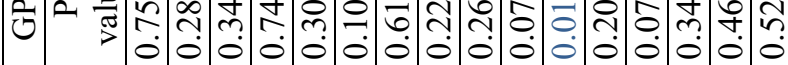

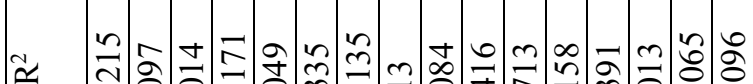
$\approx$ งิ

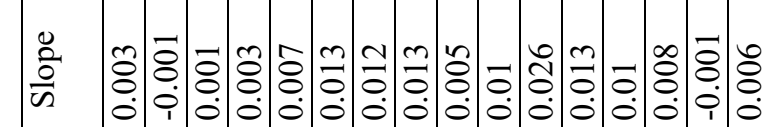

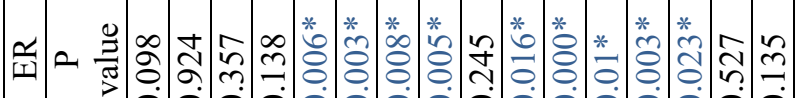

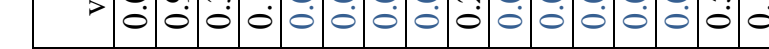

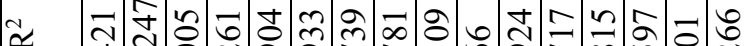

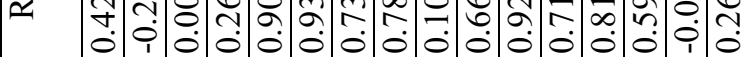
萠

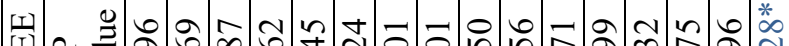

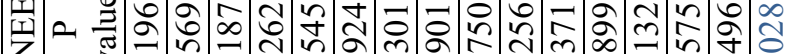

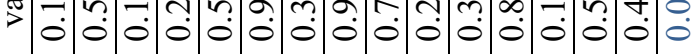

\begin{tabular}{|c|c|c|c|c|c|c|c|c|c|c|c|c|}
\hline & \begin{tabular}{|c|c|c}
$n$ & $\infty$ \\
& $\infty$ \\
0 & 0 \\
\end{tabular} & & $\mid \begin{array}{l}\vec{a} \\
\dot{0} \\
\dot{0}\end{array}$ & & 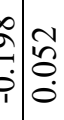 & & $\begin{array}{c}0 \\
\vdots \\
\\
\vdots\end{array}$ & $\begin{array}{l}0 \\
0 \\
0\end{array}$ & & 0 & & 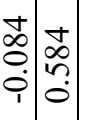 \\
\hline & 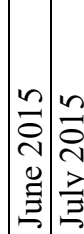 & 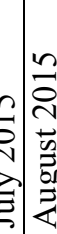 & 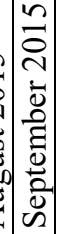 & 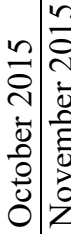 & 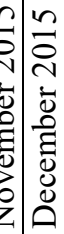 & 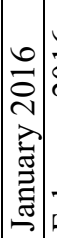 & 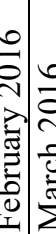 & 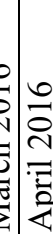 & & & & \\
\hline
\end{tabular}

